\title{
Magnetostratigraphy and paleoenvironments in shallow-water carbonates: the Oligocene-Miocene sediments of the northern margin of the Liguro-Provençal basin (West Marseille, southeastern France)
}

\author{
FRANÇOIS DEMORY ${ }^{1,2}$, GILles CONESA ${ }^{1}$, JULIEN OUDET ${ }^{1}$, HABIB MANSOURI ${ }^{3}$, PHILIPPE MÜNCH ${ }^{1}$, \\ JEAN BORGOMANO $^{1}$, NICOLAS THOUVENY ${ }^{2}$, JULIETTE LAMARCHE ${ }^{1}$, FRANCK GISQUET ${ }^{1}$ and LIONEL MARIÉ ${ }^{1}$
}

\begin{abstract}
Key-words. - Paleomagnetism, Magnetostratigraphy, Neogene, Liguro-provençal basin, Paleoenvironments, Carbonates, Paleobathymetry, Paleoclimatic changes, Geodynamics.

Abstract. - The present study proposes to estimate the influence of climate, eustatism and local tectonics on the sedimentation of a basin margin at the syn-rift to post-rift transition. For that, paleomagnetic measurements were performed on a marine marly-calcareous sedimentary succession ranging from Upper Oligocene to Lower Miocene and located on the northern margin of the Liguro-Provençal basin. The magnetostratigraphic record is correlated to the reference geomagnetic polarity scale [ATNTS04, Lourens et al. 2004] with the help of biostratigraphy based on calcareous nannofossils and planctonic foraminifers [Oudet et al., 2010]. The resulting age model shows that the $100 \mathrm{~m}$-thick sedimentary succession covers a time span of $5 \mathrm{~m}$.y. from the Late Chattian to the Early Burdigalian. Despite several exposure surfaces and a change in the sedimentation rate, no significant hiatus of sedimentation is documented. In addition, we also estimate the paleoenvironmental evolution through the sedimentary succession. Comparing the dated paleoenvironmental reconstruction with global $\delta^{18} \mathrm{O}$ and sea level curves [Miller et al., 2005], we show that the Carry-le-Rouet succession is an excellent paleoclimatic archive. Indeed, coral reefs developed at the glacial-interglacial stage transition marking the end of the Oligocene. In addition, the most diversified coral reefs occurred during the warmest period of the Aquitanian. During rifting, bathymetric variations recorded in the studied succession are related to local synsedimentary tectonics whereas, during oceanic crust accretion, global sea level changes influence the sedimentation. This result allows to characterise and to accurately date the break-up unconformity at 20.35 Ma.
\end{abstract}

\begin{abstract}
Magnéto-stratigraphie et paléo-environnements dans des carbonates peu profonds : les sédiments oligo-miocènes de la marge septentrionale du bassin liguro-provençal (ouest de Marseille, Sud-Est de la France)
\end{abstract}

\begin{abstract}
Mots-clés. - Paléomagnétisme, Magnéto-stratigraphie, Néogène, Bassin liguro-provençal, Paléoenvironnements, Carbonates, Paléobathymétrie, Changements paléoclimatiques, Géodynamique.

Résumé. - La présente étude propose d'estimer l'influence du climat, de l'eustatisme et de la tectonique locale sur la sédimentation d'un bassin marginal à la transition syn-rift - post-rift. Pour cela, des mesures paléomagnétiques ont été effectuées sur une succession sédimentaire marno-calcaire marine d'âge Oligocène supérieur à Miocène inférieur localisée sur la marge septentrionale du bassin liguro-provençal. L'enregistrement magnéto-stratigraphique a été daté par une biostratigraphie basée sur les nannofossiles calcaires et les foraminifères planctoniques [Oudet et al., 2010]. Ensuite, cet enregistrement a été corrélé à l'échelle de polarité géomagnétique de référence [ATNTS04, Lourens et al., 2004]. Le modèle d'âge résultant montre que la succession sédimentaire de $100 \mathrm{~m}$ d'épaisseur couvre 5 millions d'années du Chattien supérieur au Burdigalien inférieur. Malgré trois surfaces d'émersion et un changement de taux de sédimentation, aucun hiatus majeur de sédimentation n'est observé. De plus, nous avons estimé l'évolution paléoenvironnementale le long de la succession sédimentaire. En comparant les reconstitutions paléoenvironnementales datées avec les courbes globales de $\delta^{18} \mathrm{O}$ et du niveau marin global [Miller et al., 2005], nous mettons en évidence que la succession de Carry-le-Rouet est une excellente archive paléoclimatique. En effet, les récifs coralliaires se sont développés à la transition glaciaire-interglaciaire marquant la fin de l'Oligocène. De plus, les récifs coralliaires les plus diversifiés se développent durant la période la plus chaude de l'Aquitanien. Pendant le rifting, les variations bathymétriques enregistrées dans la succession étudiée sont attribuées à la tectonique locale, alors que durant la phase post-rift, les changements du niveau marin relatif influencent la sédimentation. Ce résultat permet de caractériser et de dater précisément le passage syn-rift post-rift à 20,35 Ma.
\end{abstract}

1. Laboratoire de Géologie des Systèmes et Réservoirs Carbonatés, EA 4234, 3 place Victor Hugo, 13331 Marseille cedex 03, France.

2. CEREGE, Equipe de Géophysique, BP 80, Europôle de l'Arbois, 13545 Aix-en-Provence cedex 04, France.

3. Laboratoire de Paléontologie stratigraphique et Paléoenvironnement, Département des Sciences de la Terre, Université d'Oran, BP 1524, El M’Naouer, Oran, Algérie. 


\section{INTRODUCTION}

The syn-rift to post-rift transition during basin opening is marked by the shift of deformation from the margin to the basin due to oceanic crust accretion. This shift affects sedimentation on the basin margin [Einsele, 2000 and references therein]. During rifting, sedimentation occurs on tilted blocks and under a strong tectonic activity whereas during post-rifting, sediments are deposited under quiet tectonic conditions. The syn-rift to post-rift transition is marked on seismic profiles by a break-up unconformity, separating syn-rift sedimentary bodies with complex geometries from large and flat post-rift sedimentary bodies [e.g., Gorini et al., 1993]. Nevertheless, the age of the unconformity is not precise because the seismics and wells stratigraphy is of low resolution. On the contrary, field investigations on margin sediments may help to accurately characterize and date the break up unconformity. In addition, the paleoenvironmental study of syn-rift and post-rift sediments lying on a basin margin is of high interest since it allows to estimate the relative influence of climate, glacio-eustatism and tectonics on sedimentation.

The Late Oligocene-Early Miocene sedimentary rocks lying on the northern margin of the Liguro-Provençal basin result from sedimentation composed both of siliciclastic and carbonate input and of in-situ carbonate production. This sedimentation is influenced by tectonics since it overlaps the transition from continental rifting to basin opening. In the Gulf of Lion, i.e. on the western part of the margin, the syn-rift to post-rift transition was roughly dated at 21.5 Ma [e.g., Dèzes et al., 2004]. A recent synthesis has shown that the age of the transition is poorly constrained and ranges from 19 to $23 \mathrm{Ma}$ [Bache et al., 2010]. The margin sedimentation is also influenced by global climatic and glacio-eustatic changes occurring at this period and related to large Antarctic glaciations [e.g., Zachos et al., 2001; Naish et al., 2001]. In addition, this sedimentary record is the most preserved and diversified coral-reef environment of the French Mediterranean coast documented for this period [Chevalier, 1961]. Therefore, the geodynamic and climatic context makes the sedimentary record of high interest for paleoenvironmental reconstructions. In this framework, a precise dating of the paleoenvironmental reconstructions is a key to estimate the location and the age of the break-up unconformity and to unravel the sedimentological history of the margin during the Liguro-Provençal basin opening.

For a long time, chronostratigraphy of the considered sedimentary column has been difficult to establish. Indeed, no radiochronology could be performed since volcanic layers are absent. In addition, shallow water marly-carbonate sediments contain few microfossils. Consequently, biostratigraphy based on rare foraminifers provides scarce indirect dating points [Anglada, 1972; Maurel-Ferrandini, 1976].

Paleomagnetic investigations have rarely been performed in carbonates since the paleomagnetic signal is generally weak and unstable. However paleomagnetism in carbonates is successful when the carrier of the paleomagnetic signal is a biomagnetite [e.g., Aïssaoui et al., 1990] or a magnetite from detrital origin [e.g., Cabioch et al., 2008]. Nowadays, the limitation due to the signal weakness can be overcome by the use of the last generation of high sensitivity superconducting magnetometers. The instability of the signal, probably linked to heterogeneous magnetic mineralogy, can be overcome by the measurement of numerous samples in each layer and by a careful selection of high quality data. In addition, complete remagnetization could affect carbonates after sedimentation. This impedes the characterization of primary magnetization and, consequently, paleomagnetic dating of sedimentary rocks. Remagnetizations are due either to burial diagenesis or to orogenic fluid migrations at regional scale [e.g., Katz et al., 1998].

The aim of this study is to build up a geomagnetic polarity record from high quality data, anchored with a brand-new and robust biostratigraphy [Oudet et al., 2010] and correlated with a reference geomagnetic polarity reference scale ATNTS04 [Lourens et al., 2004]. The resulting age model will be discussed in terms of sedimentation rates and possible sedimentary hiatuses. Paleomagnetic dating of the paleoenvironments in the study area will enable us to discuss the margin evolution regarding global paleoclimatic and sea level variations and regional geodynamics.

\section{GEOLOGICAL SETTINGS}

\section{Geodynamic context}

A continuous succession of continental and marine sediments of Late Oligocene to Early Miocene age is exposed along the coast of Carry le Rouet, near Marseille (figs 1,2). The sediments were deposited on the northern margin of the Liguro-Provençal basin, which opened in two steps: a syn-rift phase from 30.0 to $21.5 \mathrm{Ma}$ followed by a post-rift stage with ocean crust accretion from 21.5 to $14.0 \mathrm{Ma}$ [Gattacceca, 2000; Gattacceca et al., 2007 and references therein]. These steps are associated with the anticlockwise rotation and the southeastwards drift of the Corsica-Sardinia continental block (fig. 1) [e.g., Westphal et al., 1976; Gattacceca, 2000; Gattacceca et al., 2007]. The break-up unconformity between syn-rift and post-rift sediments has been identified on seismic profiles [Gorini et al., 1993] and dated between 19 and $23 \mathrm{Ma}$ [Bache et al., 2010 and references therein].

\section{Lithostratigraphy}

Since Matheron [1839] numerous regional studies were devoted to the geology of the sedimentary succession of Carry le Rouet [e.g., Andreieff et al., 1972; Monleau et al., 1988; Nury, 1990; Nury and Thomassin, 1994; Borgovini, 2003; Galloni, 2003; Conesa et al., 2005a; Besson et al., 2005; Oudet, 2008; Oudet et al., 2010].

The Late Oligocene-Early Miocene sedimentary succession of the Carry-le-Rouet area (fig. 2) reaches a total thickness of about $130 \mathrm{~m}$. The present study focuses on the topmost $100 \mathrm{~m}$ of the succession in which marine influences are observed. Layers gently dip southwestward $\left(\sim 4^{\circ}\right)$. The outcrops are exposed in a band $8 \mathrm{~km}$ long and up to $2 \mathrm{~km}$ wide along the east-west coast. The sedimentary succession unconformably overlies a deformed and eroded Mesozoic basement (fig. 2). This succession is composed of six lithostratigraphic units [Andreieff et al., 1972]. The conglomeratic Rouet unit consists of fluvial deposits with marine influences in the topmost $8 \mathrm{~m}$ (Unit 1, fig. 3). The parareefal Cap de Nautes unit (Unit 2), the brackish Rousset 


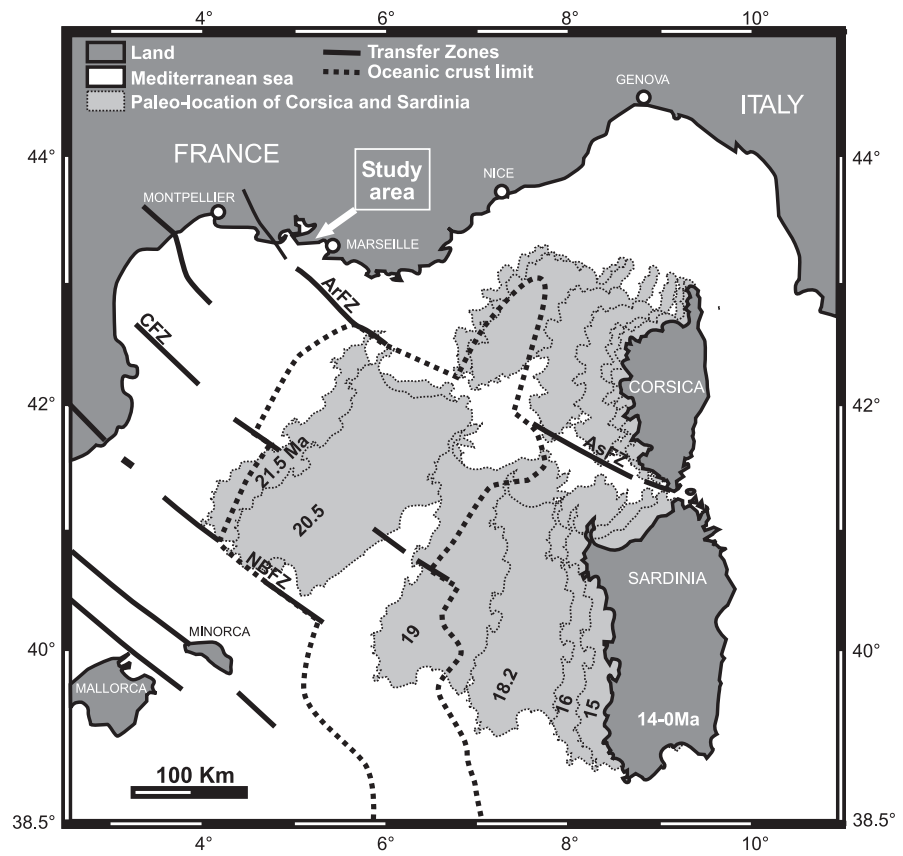

FIG. 1. - Geodynamic context of the study area in the frame of Corsica-Sardinia anticlockwise block rotation and Liguro-Provençal basin opening. Paleo-locations of Corsica and Sardinia from $30 \mathrm{Ma}$ before to present day after Gattacceca et al. [2007]; transfer zones and present-day oceanic crust limit after Maillard et al. [2003]. ArFz: Arlesian fracture zone; CFZ: Catalan fracture zone; NBFZ; North-Balearic fracture zone.

FIG. 1. - Contexte géodynamique de la zone d'étude dans le cadre de la rotation antihoraire du bloc corso-sarde et l'ouverture bu bassin liguro-provençal. Paléo-localisations de la Corse et de la Sardaigne de $30 \mathrm{Ma}$ jusqu'à présent d'après Gattacceca et al. [2007] ; zones de transfert et limite actuelle de la croûte océanique selon Maillard et al. [2003] ; ArFz zone de fracture arlésienne; CFZ : zone de fracture catalane; NBFZ, zone de fracture nord Baléares.

unit (Unit 3), the bioclastic Carry unit (Unit 4), the biodetrital Sausset unit (Unit 5) and the Plan de Sausset unit (Unit 6) are composed of marine and marine-continent transitional deposits (figs 3,4).

\section{Biostratigraphy}

The biostratigraphic dating of the Carry-le-Rouet succession was previously established using foraminifers and continental gastropods [Anglada, 1972; Maurel-Ferrandini, 1976; Nury, 1990]. Unit 1 was attributed to the late Chattian (late Oligocene) on the basis of large specimens of helicid gastropod Wenzia ramondi [Nury, 1990]. According to the foraminifer biostratigraphic chart of Blow [1969], Anglada [1972] assigned an Aquitanian age to units 4 and 5. In unit 4, Anglada [1972] observed, at the base of the Rousset marls (fig. 2), the lowest occurrence of the epiplanctonic foraminifer assemblage Globigerina praebulloides occlusa / Globigerinoides quadrilobatus primordius. He attributed this assemblage to the base of the N4 foraminifer zone and thus to the beginning of the Miocene. Anglada [1972] also reported the coexistence of Globigerinoides quadrilobatus primordius / Globigerinoides quadrilobatus quadrilobatus within the Tuilières marls (fig. 2) of unit 5 (fig. 3). He related the last occurrence of this assemblage either to the end of the N4 zone or to the beginning of the N5 zone. Finally a Burdigalian age based on planctonic foraminifers and larger benthic foraminifers was established for unit 6 by Maurel-Ferrandini [1976]. The author attributed the lowest occurrence of the assemblage Globigerinoides trilobus trilobus / Globigerinoides altiaperturus to the beginning of the N6 zone. In addition Maurel-Ferrandini [1976] found Miolepidocyclina burdigalensis, which is a larger benthic foraminifer characteristic for Early Burdigalian age, at the base of unit 6 .

A new biostratigraphy based on calcareous nannofossils and planctonic foraminifers [Oudet et al., 2010] was performed and calibrated to the very last geological time scale [Gradstein et al., 2004; Ogg et al., 2008]. This biostratigraphy was used in the present study in order to constrain the paleomagnetic correlations. The nannofossil stratigraphy shows that:

- the lowest occurrence (LO) of Sphenolithus delphix was observed at $\sim 11 \mathrm{~m}$, the first appearance datum (FAD) of this species is $23.21 \mathrm{Ma}$;

- the LO of Helicosphaera ampliaperta was observed at $\sim 81.5 \mathrm{~m}$, its FAD is $20.43 \mathrm{Ma}$;

- the LO of Sphenolithus belemnos was observed at $\sim 98 \mathrm{~m}$, its FAD is $19.03 \mathrm{Ma}$.

The planctonic foraminifer stratigraphy shows that:

- the LO of Globoquadrina dehicens was observed at $\sim 50 \mathrm{~m}$, its FAD is $22.38 \mathrm{Ma}$;

- the LO of Paragloborotalia incognita was observed at $\sim 66.5 \mathrm{~m}$, its FAD is $20.93 \mathrm{Ma}$;

- the LO of Globigerinoides altiaperturus was observed at $\sim 84 \mathrm{~m}$, its FAD is $20.06 \mathrm{Ma}$.

\section{MATERIAL AND METHODS}

\section{Stratigraphic description}

In order to perform the paleomagnetic and paleoenvironmental studies, a bed-by-bed lithological log was constructed for the Late Oligocene-Early Miocene sedimentary marine succession. The $100 \mathrm{~m}$-thick synthetic stratigraphic column was based on six logs distributed along the Carry-le-Rouet rocky coast (fig. 2). These logs were correlated together using several marker beds (fig. 3: mb1 to $\mathrm{mb} 7$ ) of 0.5 to $3 \mathrm{~km}$ lateral extension (fig. 2). The logging took into account the geometry of the deposits and the lateral facies variations along the $5 \mathrm{~km}$-long cross-section. Facies and biological component descriptions were based on field observations and thin sections observations.

\section{Paleomagnetism and rock magnetism}

A Pomeroy hand drill was used to collect 106 cores from 58 sedimentary levels. The cores were cut in $22 \mathrm{~mm}$-long cylindrical samples resulting in 213 samples. Oriented blocks retrieved from 3 marly levels were sub-sampled using 8 plastic boxes of $8 \mathrm{~cm}^{3}$.

Stepwise thermal demagnetisation was performed on 208 samples. Natural remanent magnetisation (NRM) and remanent magnetisation at steps 100, 200, 300, 350, 400 and $450^{\circ} \mathrm{C}$ were measured using the superconducting rock magnetometer 2G760R (2G enterprises) of CEREGE (Aixen-Provence, France). The demagnetisation step $450^{\circ} \mathrm{C}$ was sufficient to remove the viscous overprint and to reveal the primary paleomagnetic signal. Thermomagnetic 


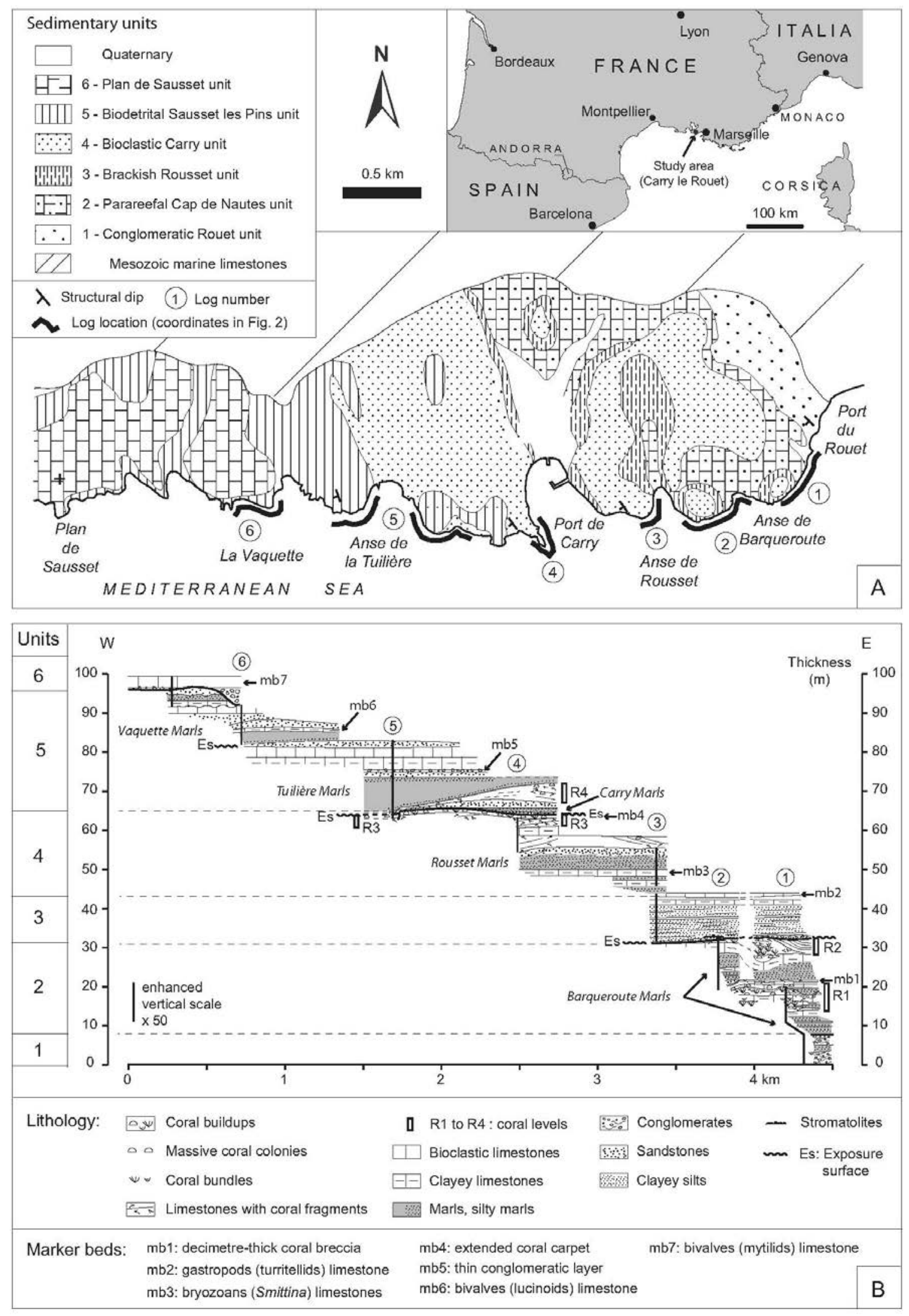

FIG. 2. - A : Geological map of Carry-le-Rouet area modified from Andreieff et al. [1972]; B: east-west cross-section of stratigraphic units with marker beds, lithology, and logs position (encircled numbers). Dips are corrected.

FIG. 2. - A : Carte géologique du secteur de Carry-le-Rouet [modifié d'après Andreieff et al., 1972] ; B : Coupe E-W des unités stratigraphiques avec les niveaux marqueurs, la lithologie et la position des logs (nombres entourés). Les pendages sont corrigés. 
measurements have shown that neoformation of magnetite above $450^{\circ} \mathrm{C}$ may affect the remanent magnetization. Stepwise alternating field demagnetisation was performed on 13 samples ( 5 cylinders and 8 filled plastic boxes) which were too brittle for heating. Natural remanent magnetisation and remanent magnetisation were measured at steps 2.5, 5, $10,15,20,30,45,60,80$ and $100 \mathrm{mT}$. All paleomagnetic data were treated using the PaleoMac software [Cogné, 2003].

In order to preserve samples for paleomagnetic investigation, rock magnetic analyses were only conducted on fragments resulting from cylinder preparation. We investigated temperature dependence of magnetic susceptibility up to a maximum temperature of $600^{\circ} \mathrm{C}$ on 5 representative samples using a CS2 furnace attached to a Kappabridge KLY2 magnetic susceptibility meter (AGICO) [Hrouda, 1994].

\section{RESULTS}

\section{Stratigraphic description}

This following description includes lithology, fossil assemblages, lateral facies variations, geometry of sedimentary bodies and noticeable exposure surfaces. This description will be used for paleoenvironmental interpretations.

\section{- Upper part of unit 1 (log section: 4-8 m)}

This upper part is characterized by a yellow detrital interval (fig. 3; $\log$ section: 4-7 m) of clast-supported, chenalized conglomerates, limy sandstones, and clayey siltstones. These deposits include fragments of bivalves, oysters, gastropods, very rare rhodoliths, and clasts with sponge-borings. Thick lamellar to branching coral-colonies (poritids), in-life position, encrust clasts from the top of the first conglomeratic bed and build a thin coral carpet [Galloni, 2003]. A single lobe-shaped conglomerate with rare oysters clasts-incrustation, displays beach features like low angle stratification, and very well-sorted and well-rounded pebbles. The yellow interval is intercalated with red detrital deposits (fig. 4A). These deposits are azoïc, clast-supported conglomeratic beds and clayey interbeds showing paleosoils and pulmonate gastropods (fig. 3: log sections: 0-4 $\mathrm{m}$ and 7-8 m; fig. 4A) [Nury, 1990]. The conglomeratic beds are composed of mutually erosive, nested channels. The yellow interval discordantly erodes the underlying deposits and is itself deeply incised by red conglomeratic channels (fig. 4A). Clasts from unit 1 are pebbles to boulders up to one meter in size. A predominant clasts fraction is composed of Barremian rudists limestones observed in the Nerthe nearby outcrops. A minor clast fraction consists of siliceous clasts (Permo-Triasic radiolarites, quartzites...) from far-distant and diverse sources.

\section{- Unit 2 (log section: 8-3 m)}

This unit onlaps unit 1. It exhibits two discontinuous levels of several vertical-stacked coral biostromes and derived bioclastic deposits sometimes mixed with sandstones (figs 2, 3, 4B: R1, R2), and two interbedded marly intervals (Barqueroute marls) [Borgovini, 2003; Galloni, 2003]. The first interval is composed of shelly marls with coal and the second one of silty marls with sandstone beds. Both marly intervals include bioclastic, clayey beds. The coral biostromes are lense-shaped bodies up to a few meters thick and a few hundred meters to one kilometer wide (figs 2, 4B). They pinch out laterally with a slope composed of coral breccias and clayey bioclastic limestones (figs 2, 3, 4B). The coral assemblage is set in clayey, bioclastic limestones or sandstones. It consists of in-life-position, coalescent or scattered, massive colonies and bundles of poritids and faviids, bundles of mussids, and of fragments of branching acroporitids and poritids [Galloni, 2003] (fig. 3). Associated organisms are molluscs, echinoids (scutellids), red coralline-algae, and larger hyaline benthic foraminifers (lepidocyclinids, miogypsinids, and amphisteginids). Bushy rhodoliths commonly coat coral fragments. Bivalves (including the pectinid Amussium) and porcelaneous foraminifers (miliolids, austrotrillinids and soritids) can be abundant within the marly intervals. Planktonic foraminifers (globigerinids) are rare or lacking. Reworked tree fragments occur within bioclastic, clayey limestones at the top of the unit (fig. 3).

\section{- Unit 3 (log section: 32-43 m)}

The lowermost part of this unit exhibits a coral breccia with siliceous pebbles, shelly coarse-grained sandstones, and a level of stromatolites encrusting reworked trees fragments (figs 2, 3, 5A) [Andreïeff et al., 1972]. The sandstones also form the coral breccia matrix and fill bioturbations developped down to the clayey limestones from the topmost part of unit 2. Deposits overlying stromatolites are thin-bedded, clayey limestones and sandstones, both interbedded with shelly, silty marls and fine-grained sands (fig. 4B). Fossils are thin bivalve-shells, reworked stromatolitic fragments and small benthic foraminifers including rare miliolids. Gastropods potamids (fig. 5B), mytilids and oysters, and rare coral-fragments are observed in the upper part of the unit. Planktonic foraminifers have not been observed [Anglada, 1972].

\section{- Unit 4 (log section: 43-66 m)}

The lower part of this unit is represented by bioclastic limestones interbedded with silty marls and fine-grained sands, and by the Rousset marls (log section: 43-53 m; figs 2, 3, 4C). The bottom surface of the first bed is slightly erosive on unit 3, with lag deposits composed of siliceous pebbles and oysters fragments. Several limestone beds and marly interbeds host reworked abundant gastropods (fig. 5C: endobiont turritellids), bivalves, and, or fragmented colonies of erect rigid bilamellar bryozoan Smittina [fig. 5D; Moissette, pers. com.]. Subordinate organisms are echinoids, reworked and smoothed coral fragments, small benthic foraminifers, and globigerinids planctonic foraminifers [Anglada, 1972]. The upper part of this unit comprises lobe-shaped, cross-bedded siltstones to sandstones, laterally interbedded with the Rousset marls, cross-bedded bioclastic limestones with turritellids, bryozoans and scattered corals fragments, and two coral-levels (log section: 53-66 m; figs 2, 3, 4C, 4D: R3, R4). The siliciclastic deposits are coarsening-upward sorted. They show, from bottom to top, planar laminations, hummocky cross-stratification (HCS), and megaripples [Borgovini, 2003]. They contain reworked fragments of benthic 


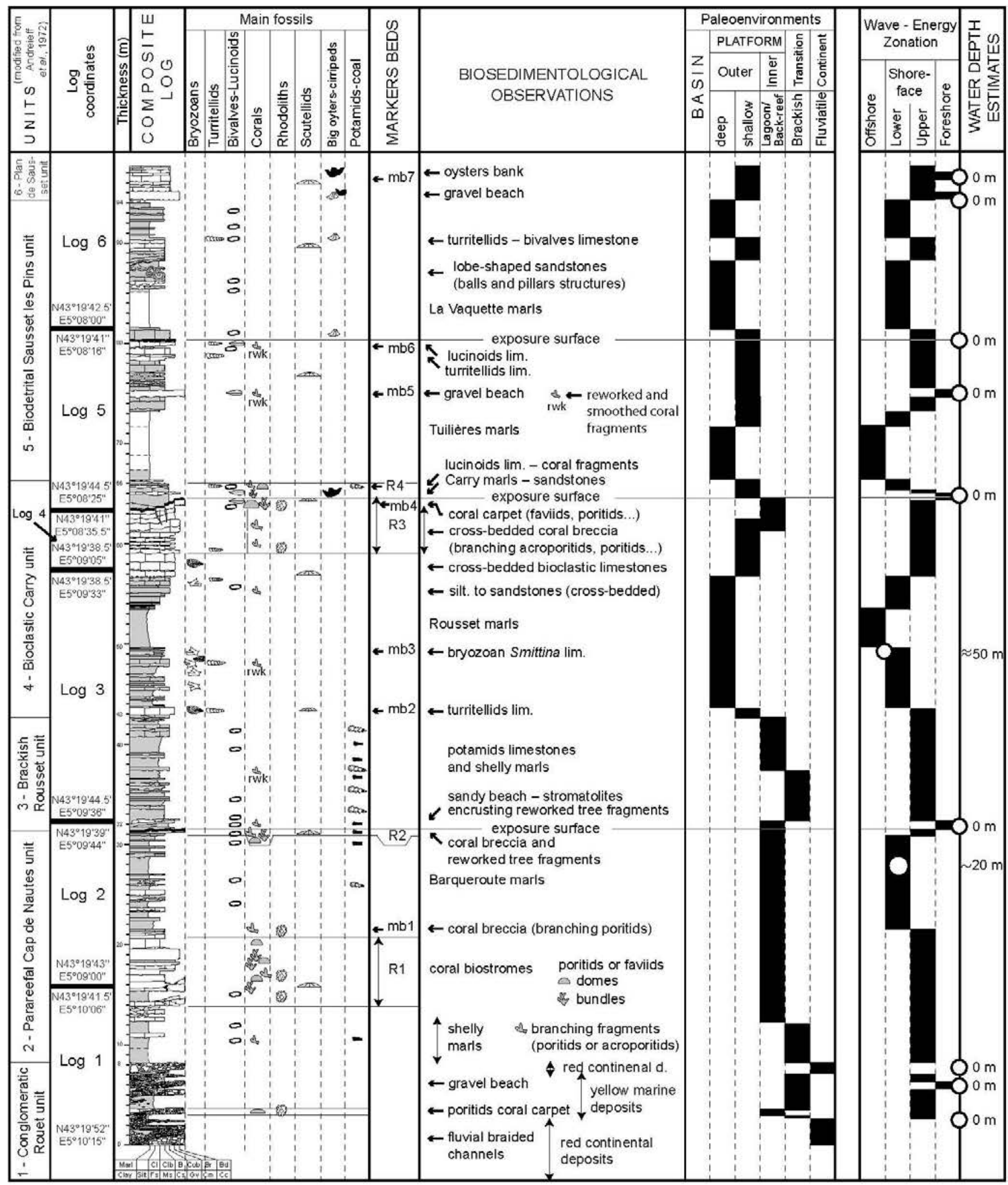

\begin{tabular}{|c|c|c|c|c|c|}
\hline \multirow{3}{*}{$\begin{array}{l}\text { Lithology } \\
\text { Carbonate: } \square \\
\text { (Bd) Coral build-up } \\
\text { (Br) Coral breccia } \\
\text { (Cob) Coarse \& bioclastic } \\
\text { (B) Bioclastic } \\
\text { (Clb) Clayey \& bioclastic } \\
\text { (Cl) Clayey } \\
\text { Marls }\end{array}$} & \multirow{3}{*}{\begin{tabular}{l}
\multicolumn{1}{l}{ Siliciclastic: $\square$} \\
(Gv) Gravel \\
(Cs) Coarse \\
(Ms) Medium \\
(Fs) Fine \\
Silt \\
Clay \\
Conglomerate: \\
Matrice supported $(\mathrm{Cm})$
\end{tabular}} & \multicolumn{3}{|l|}{ Characteristic Fossils } & \multirow{2}{*}{$\begin{array}{l}\text { Others } \\
\mathrm{R} 1 \text { to } \mathrm{R} 4=\text { coral levels } \\
\mathrm{mb} 1 \text { to } \mathrm{mb} 7=\text { markers beds } \\
\\
(\text { Fig. } 1)\end{array}$} \\
\hline & & $\begin{array}{l}\Rightarrow \text { bryozoan Smittina } \\
\text { others bryozoans } \\
\Leftrightarrow \text { turritellids } \\
\text { lucinoids } \\
\text { bivalves }\end{array}$ & $\begin{array}{l}\triangle \text { domal } \\
\text { lamellar } \\
\text { bundles } \\
\text { fragments } \\
\text { scutellids }\end{array}$ & $\begin{array}{l}\text { Coral } \\
\text { colonies }\end{array}$ & \\
\hline & & $\begin{array}{l}\text { large oyster banks } \\
\text { large oysters }\end{array}$ & $\begin{array}{l}\text { 78 cirripeds } \\
\text { - coal fragments }\end{array}$ & & \\
\hline
\end{tabular}


foraminifers, bryozoans, red-algae, and stromatolites [Andreieff and l'Homer, 1972]. The few meter-thick coral-level R3 is composed of cross-bedded coral breccias of branching acroporitids and poritids, topped by a $2 \mathrm{~km}$-long and $0.5 \mathrm{~m}$-thick coral carpet (figs 2, 3, 4D, 5E: $\mathrm{mb} 4$ ). The coral breccias show a regular alternation of decimeter-thick bioclastic limestones and thin marls. Subordinate fossils are echinoid spines (cidarids), red algal coating on corals and lepidocyclinids. The coral carpet (sensu Riegl and Piller [1999]) is a single layer of either coalescent or scattered coral colonies in life position, settled on and buried by a bioturbated (clayey) bioclastic sediment. This coral level is the most diversified of the whole sedimentary succession [Chevalier, 1961]. Main corals are domal colonies and bundles of poritids and faviids, bundles of mussids, and thin lamellar dendrophyllids [Chevalier, 1961; Galloni, 2003]. Associated organisms are similar to those of unit 2 , including noticeable bushy rhodoliths. The coral carpet is affected by early lithification, syn-sedimentary fractures and sub-aerial exposure [Andreieff et al., 1972]. Oyster clumps and faviids bundles both in upright living position locally top the coral carpet. The overlying deposits are lobe-shaped sandstones, interbedded Carry marls with rare planctonic foraminifers, and a shelly limestone with abundant lucinoids and rare oyster encrustation (figs 2, 3, 5F). The coral-level R4 is a lobe-shaped body of one kilometer wide and a few meters thick, pinching out both to the SW and NW (figs 2, 4D) [Borgovini, 2003; Galloni, 2003]. This body exhibits bioclastic, clayey sandstones to shelly limestones with coral fragments of branching poritids and acroporids, and of massive poritids and faviids (figs 2, 3, 4D). It is topped at Port Carry by a $0.5 \mathrm{~m}$-thick coral carpet built by these massive colonies (fig. 4D). Oysters, pectinids and red algal fragments best occur in sandstones while lucinoids and turritellids are abundant in shelly limestones.

\section{- Unit $5(66-9 \mathrm{~m})$}

The unit exhibits marly interbeds with rare globigerinids (Tuillière and Vaquette marls) and lobe-shaped sandstones, shelly, bioclastic limestones, and one isopachous conglomeratic bed with well-rounded gravels and sponge borings (figs 2, 3: mb 6). Syn-sedimentary deformation affects sandstones and is expressed by up to $1 \mathrm{~m}$-thick, balls and pillars. One of the shelly limestones is blanketed by a silty mud, which fills the moldic porosity. This layer is sealed by sandstones. Fossils are composed of accumulation of bivalves (mainly lucinoids) or gastropods (turritellids), echinoids (scutellids), and coralline-algae, and rare coralfragments.

\section{- Lowermost part of unit 6 (94-98 m)}

This part exhibits a marine conglomerate covered by a bioclastic limestone (fig. 2, 3: mb 7). The conglomerate erodes the underlying unit 5 (fig. 2) and contains green-stained quartz gravels, white Mesozoic carbonate clasts, and clasts from the underlying unit [MaurelFerrandini, 1976]. All gravels are well-rounded and supported in a coarse sandy matrix. Fossils are abundant mytilids and large oysters, subordinates bivalves, cirripeds and scutellids. Oyster clumps in up-right living position may build banks in the bioclastic limestone. No corals were observed.

\section{Magnetic mineralogy}

Temperature dependence of low field magnetic susceptibility (MS) experiments were performed on five samples representative for different lithologies in order to determine Curie temperatures, which allow the identification of the carrier of remanent magnetic signal (fig. 6). The MS is low at room temperature and the signal progressively decreases with increasing temperature for samples CLR104, CLR88 and CLR65 down to negative values (fig. 6A, 6B and 6C). This progressive decrease is attributed to the behaviour of paramagnetic particles such as clays. The negative values of MS observed at high temperature are attributed to diamagnetic contribution of carbonates. The heating curves also show that the MS signal strongly falls at $360^{\circ} \mathrm{C}$ and from $420^{\circ} \mathrm{C}$ to $580^{\circ} \mathrm{C}$ for samples CLR104, CLR88 and CLR65 (fig. 6A, 6B and 6C) indicating the probable occurrence of iron sulphides and titanomagnetite, respectively. Sample CLR65 is, in addition, characterised by a pronounced MS fall at $\sim 590^{\circ} \mathrm{C}$ (fig. 6C). This temperature corresponds to the Curie point for pure magnetite. The cooling phases show the reversibility of the curves with MS increases at $590^{\circ} \mathrm{C}$ and between $420^{\circ} \mathrm{C}$ to $580^{\circ} \mathrm{C}$, confirming the occurrence of magnetite and titanomagnetite, respectively (fig. 6A, 6B and 6C). Some curves present secondary formation of ferromagnetic particles during heating (fig. 6D). MS is negative and close to zero at the beginning of the heating run. MS increases at $\sim 450^{\circ} \mathrm{C}$ and reaches $710^{-6} \mathrm{SI}$ $\mathrm{g}^{-1}$ at $560^{\circ} \mathrm{C}$ for sample CLR92 and at $\sim 520^{\circ} \mathrm{C}$ and reaches $1010^{-6} \mathrm{SI} \mathrm{g}^{-1}$ at $560^{\circ} \mathrm{C}$ for sample CLR 73. MS decreases down to negative values at $\sim 590^{\circ} \mathrm{C}$ in both heating curves. Strong MS increase in heating curves CLR 92 and CLR73 are assignable to the formation of secondary magnetite as the decrease of MS happens at $\sim 590^{\circ} \mathrm{C}$, which is the Curie temperature for magnetite. Secondary formation of magnetite is commonly reported from thermomagnetic measurements in carbonates [e.g., Schneider et al., 2004]. This shows that heating the samples at higher temperatures than $450^{\circ} \mathrm{C}$ would lead to the acquisition of an artificial magnetization through the secondary formation of magnetite. This

FIG. 3. - Late Oligocene - Early Miocene sedimentary succession of Carry-le-Rouet, with GPS coordinates of logs, main fossils, paleoenvironments, wave energy zonation and water depth estimates.

FIG. 3. - Succession sédimentaire Oligocène supérieur-Miocène inférieur de Carry-le-Rouet avec les coordonnées GPS des logs, les principaux fossiles, les paléo-environnements, la zonation d'énergie des vagues et l'estimation de la profondeur d'eau. 

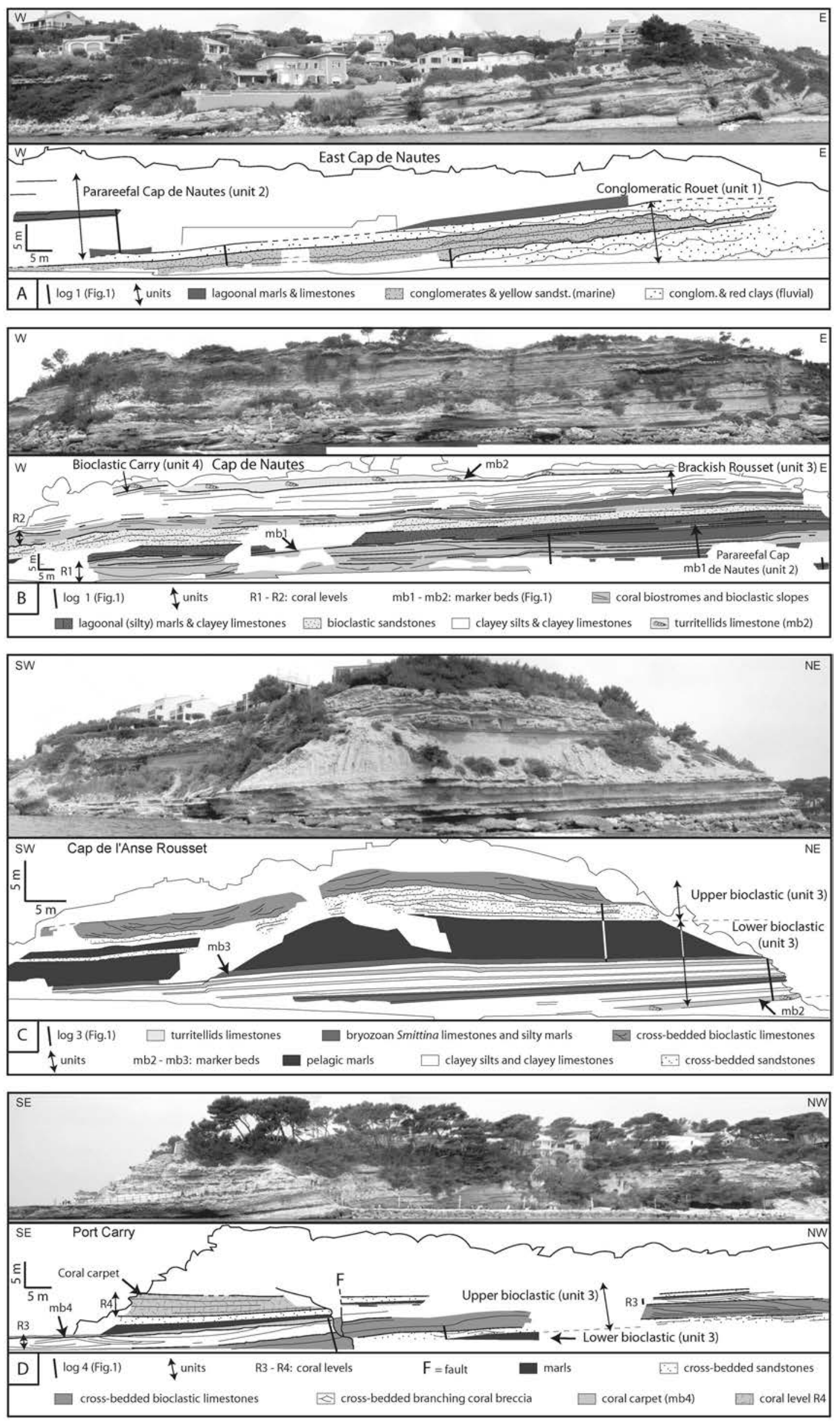

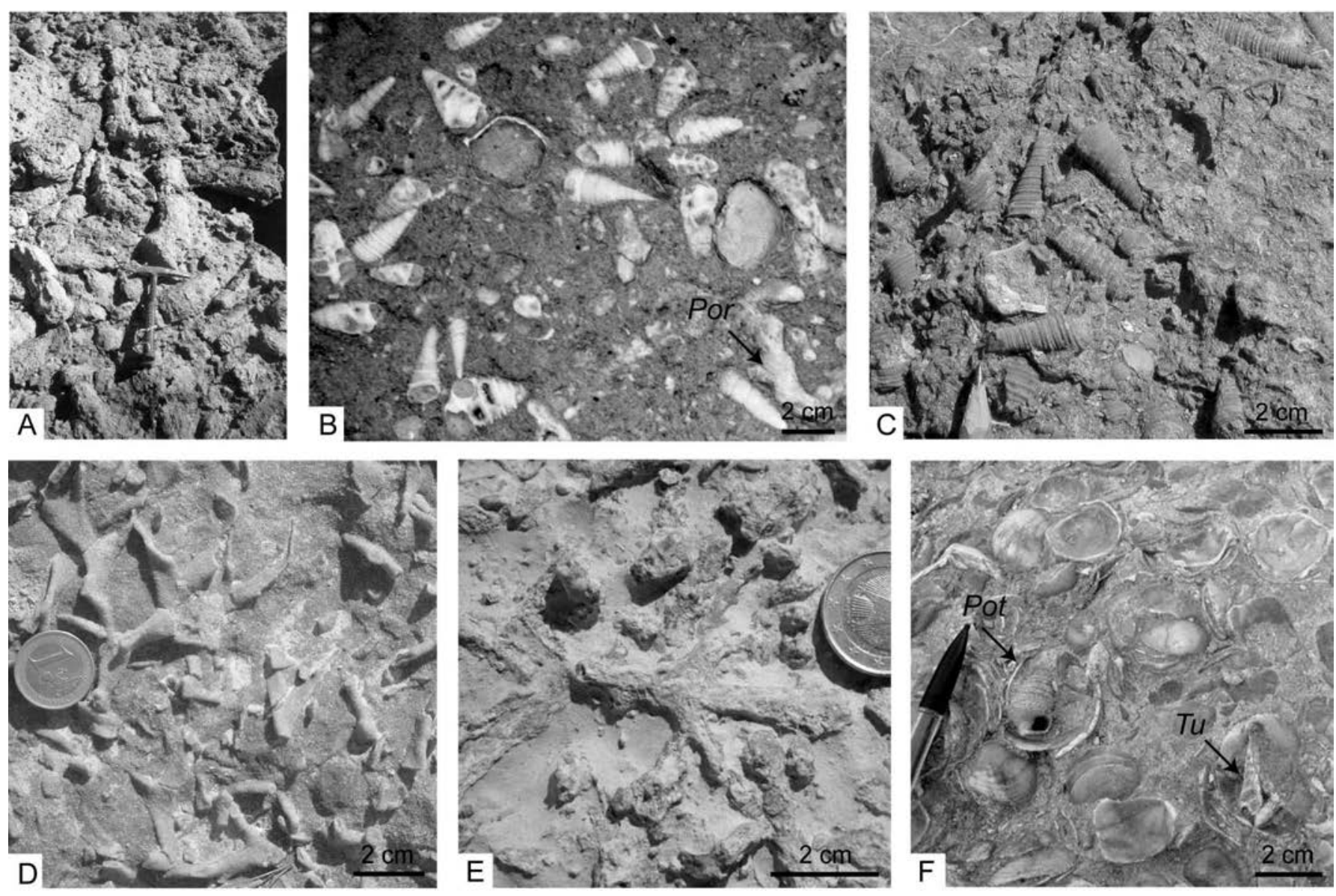

FIG. 5. - Photographs of fossiliferous facies in Carry-le-Rouet sedimentary succession; A: stromatolitic coats on trees fragments - unit 3 - west Anse de Barqueroute; B: potamids-rich clayey limestone; Por = poritids fragments - unit 3 - east anse de Rousset; C: turritellids-rich limestone; D: bryozoan Smittina-rich clayey limestone - unit 4 - east Anse de Rousset; E: coral breccia with acroporids branching fragments in a muddy matrix and F: lucinoids-rich limestone; Pot = potamids; Tu = turritellids - unit 4 - east Port de Carry.

FIG. 5. - Photographies des faciès fossilifères de la succession sédimentaire de Carry-le-Rouet; A : fragments d'arbres encroûtés par des stromatolites Unité 3 - ouest de l'anse de Barqueroute ; B : calcaire argileux riche en potamides ; Por = fragments de poritidés - Unité 3 - est de l'anse Rousset ; C : calcaire riche en turritelles ; D : calcaire argileux riche en bryozoaires Smittina - Unité 4 - est de l'anse de Rousset; E : brèche corallienne avec des fragments d'acroporidés branchus dans une matrice argileuse et $F$ : calcaire riche en lucines; Pot = potamides ; Tu = turritelles-Unité $4-$ est du port de Carry.

would be responsible for a complete overprint of the primary magnetization. The magnetic mineralogy determination shows that the magnetic assemblage is not constant and that the contribution of more than one ferromagnetic phase can be documented. It shows also that heating above $\sim 450^{\circ} \mathrm{C}$ can be responsible for secondary mineralization of ferromagnetic particles. Magnetite, which is the most convenient carrier of paleomagnetic signal, is identified. This shows that paleomagnetic studies can be performed. However, the protocol must avoid very high temperature demagnetisation and a careful selection of high quality data is needed.

\section{Demagnetisation of the natural remanent magnetisation (NRM)}

Orthogonal projection [Zijderveld, 1967], stereographic plots and demagnetization diagrams of stepwise thermal demagnetization of 6 selected samples are shown in figure 7. Lowest NRM intensities are in the order of $0.1 \mathrm{~mA} \mathrm{~m}-1$ (e.g., CLR51_1 in fig. 7). After several demagnetization steps, the remanent magnetization intensity decreases down to $0.01 \mathrm{~mA} \mathrm{~m}-1$. A strong fall of the intensity for sample CLR 110_1 at $\sim 300^{\circ} \mathrm{C}$ may suggest the presence of iron suphides, which have nevertheless not been evidenced in

FIG. 4. - Interpreted photographs of the Carry-le-Rouet sedimentary architecture with stratigraphic subdivision, marker beds, and logs location. A: East Cap de Nautes; B: West Cap de Nautes; C: Cap de l'Anse Rousset; D: Port Carry.

FIG. 4. - Photographies interprétées de l'architecture sédimentaire de Carry-le-Rouet avec la subdivision stratigraphique, les bancs marqueurs et la localisation des logs. A : Est de Cap de Nautes; B : Ouest de Cap de Nautes ; C : Cap de l'Anse Rousset ; D : Port Carry. 


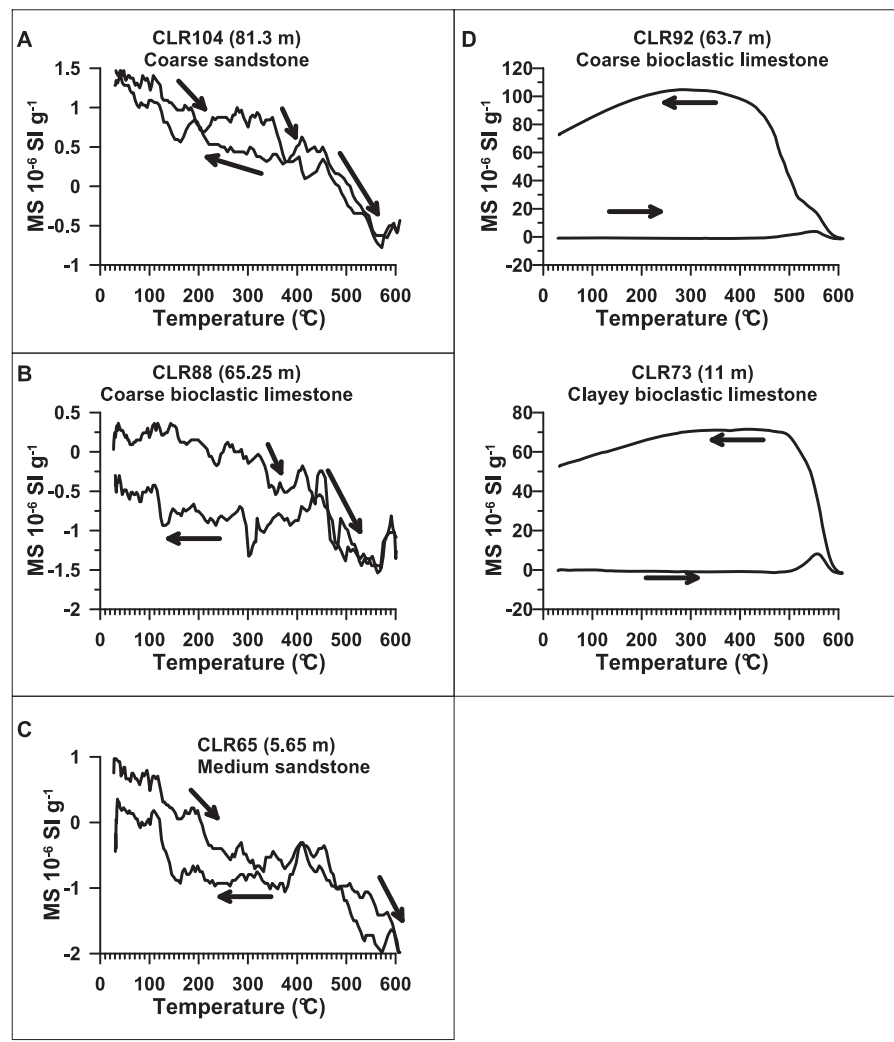

FIG. 6. - Low field magnetic susceptibility (MS) versus temperature for 5 selected samples. The black and grey curves correspond to the heating and cooling phases, respectively. The diamagnetic contribution of the oven has been subtracted from the data.

FIG. 6. - Susceptibilité magnétique en champ faible versus température pour 5 échantillons représentatifs. Les courbes noires et grises correspon dent respectivement aux phases de chauffe et de refroidissement. La contribution diamagnétique du four a été soustraite des données.

the magnetic mineralogy. These intensities are low but can still be detected by the magnetometer. Thermal demagnetisations show that the viscous overprint is generally removed below $200^{\circ} \mathrm{C}$. The inclination of the stable magnetisation is coherent with the geomagnetic inclination expected for the estimated paleolatitude (inclination of $54.5^{\circ}$ for a paleolatitude of $35^{\circ} \mathrm{N}$ in case of normal polarity) considering the $20^{\circ}$ of uncertainty linked to the paleosecular variations (CLR18_1, CLR92_1 and CLR31_1 in fig. 7). A normal overprint is observed on curves presenting a reverse polarity, avoiding a mis-orientation of the samples (CLR23_3, CLR51_1 and CLR110_1 in fig. 7). As expected for carbonate rocks, some demagnetisation patterns were of low quality. Whatever the demagnetisation method used, samples are affected by spurious magnetisations and no clear relationship exists between the lithology and the quality of the demagnetisation curve. For a total of 221 samples, only $169(\sim 76.5 \%)$ could be interpreted. For 138 samples characterised by high and medium quality demagnetisation curve (type 1), characteristic remanent magnetisation (ChRM) was estimated using the least squares method [Kirschvink, 1980]. For 31 samples characterised by low quality demagnetisation curve (type 2), ChRM was estimated using Fisher's statistics [Fisher, 1953].

\section{Geomagnetic polarity record (GPR)}

Inclinations and declinations of the ChRM as well as the reversal angle (RA) are displayed in figure 8. RA is defined as the angle between the determined ChRM direction of a sample and the field direction of a geocentric axial dipole of normal polarity at the coring site, i.e. $0^{\circ}\left(180^{\circ}\right)$ for a pure normal (reversed) dipole direction [Demory et al., 2005]. Determination of RA is helpful in case of noisy paleomagnetic data impeding the observation of a clear antipodality between normal and reversal polarities. Low values of RA reflect normal polarities whereas high values of RA reflect reverse polarities. Several samples measured in a single layer sometimes present dispersed inclination and declination of ChRM. This dispersion is especially expressed when reverse polarity is partially overprinted by normal polarity. The overprint persistence differs from one sample to another. This affects the orientation of the ChRM. We could attribute the dispersion to heterogeneities in the magnetic mineralogy related to sediment heterogeneities within a single layer. Therefore, an average of RA of the best quality data (type 1 , or type 2 when type 1 is absent) selected for each measured layer (fig. 8) was used to establish a geomagnetic polarity record (GPR). Averaged RA between $0^{\circ}$ and $45^{\circ}$ were assigned to normal polarities and average RA between 45 and $180^{\circ}$ were assigned to reverse polarities. This record displays several polarity changes. Remaining uncertainties concern only two layers characterised by average RA very close to $45^{\circ}$ and four short intervals presenting no data (fig. 8). The cumulative thickness with no data reaches $\sim 20 \mathrm{~m}$, what corresponds to $\sim 20 \%$ of the entire sedimentary column.

\section{INTERPRETATIONS}

Lithology, fossil assemblages, geometry of sedimentary bodies and exposure surfaces characterisation were used to reconstruct the paleoenvironmental evolution recorded in the sedimentary succession (fig. 3).

\section{Paleoenvironments}

\section{Upper part of unit 1}

This section records a transition from continental to marine environments. The red detrital deposits including nested, clast-supported channels and clays, are typical of a braided fluvial system as has been already demonstrated [Nury, 1990]. The yellow detrital interval represents a marine littoral setting with clast-supported channels and lobe-shaped conglomerates both interpreted as deltaïc distributaries and gravel beach. The thin coral carpet is the first attempt of reef building in a such detrital setting.

\section{Unit 2}

This unit represents a typical, protected inner-platform and reef-like environment, characterized by high mud decantation, abundant porcelaneous foraminifers, and scattered wide coral biostromes. The first marly interval (log section: 8-12 m) with shelly marls and coal similar to those described in the brackish unit 3, may specifically record brackish trends [Andreieff and l'Homer, 1972]. Coral fragments and larger hyaline benthic foraminifers within the second marly interval (log section: 


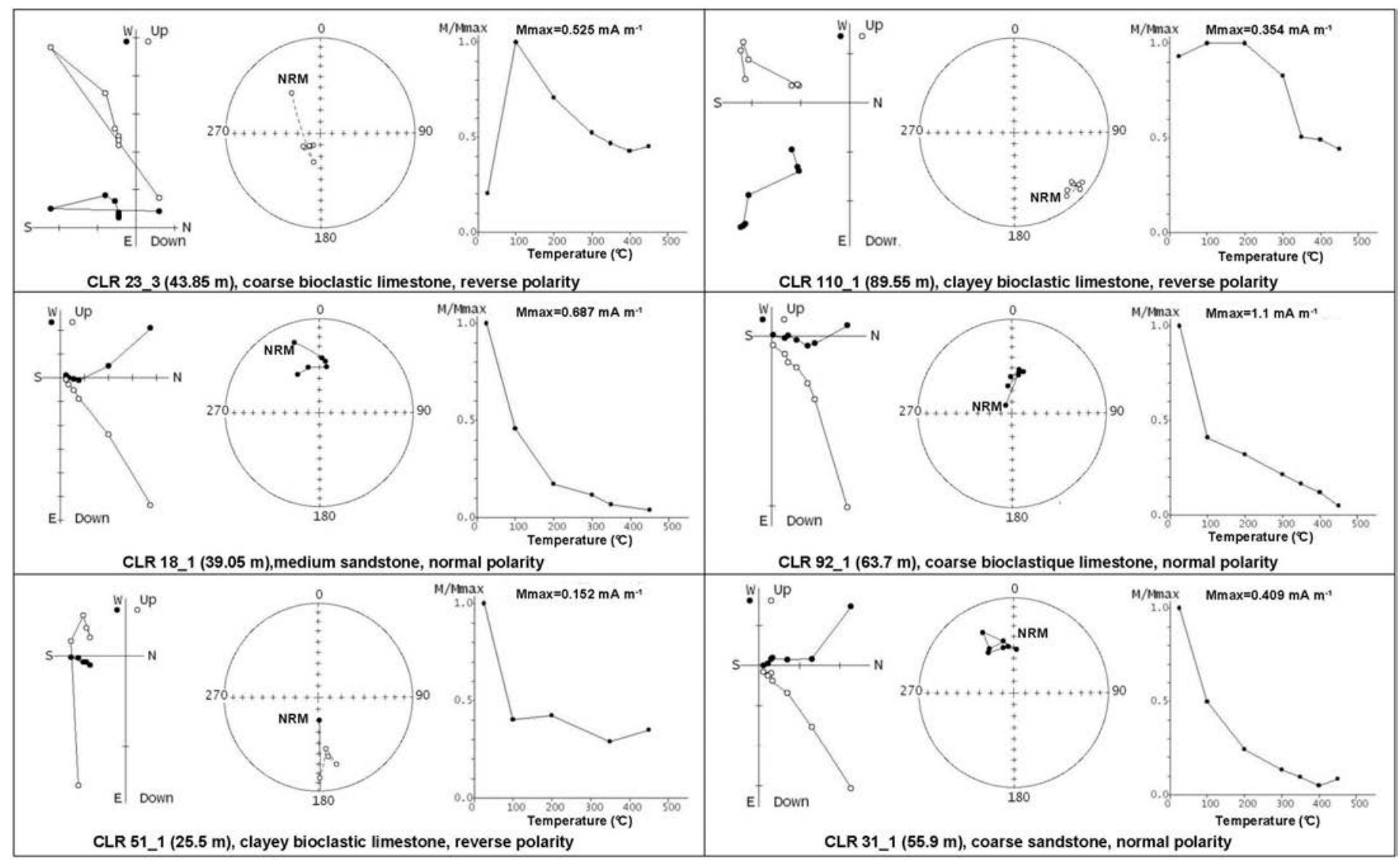

FIG. 7. - Orthogonal projections [Zijderveld, 1967], stereographic plots and demagnetization diagrams for 6 selected type 1 samples. On the orthogonal projection plots, open and solid circles represent projections on vertical and horizontal planes, respectively. On the stereographic plots, open and solid circles represent reverse and normal inclinations, respectively.

FIG. 7. - Projections orthogonales [Zijderveld, 1967], stéréographiques et diagrammes de désaimantation pour 6 échantillons de type 1. Sur les projections orthogonales, les cercles vides et pleins représentent respectivement les projections sur les plans verticaux et horizontaux. Sur les projections stéréographiques, les cercles vides et pleins représentent respectivement les inclinaisons inverses et normales.

21-31 m) represent lateral influences of coral biostromes. This interval sets in a deeper setting than the coral biostromes R1 and R2. Using the foraminifer assemblage, Anglada [1972] assigned water depths lower than $20 \mathrm{~m}$ to unit 2. Similar environmental settings have been described in Oligocene-Early Miocene platforms from Indo-Pacific region [e.g., Chapronière, 1975; Fournier et al., 2004; Conesa et al., 2005b]. The authors proposed water depths lower than $15 \mathrm{~m}$. The high content of branching coral fragments deposited in muddy, bioclastic sediment within or in the vicinity of the coral buildups, may be related to storms in a back-reef setting or to bioerosion as observed at present in the Caribbean Sea [e.g., Scoffin, 1993; Aronson and Pretch, 1997]. Nevertheless, reworked tree fragments and pebbles within a coral breccia at the top of the unit (fig. 3) are evidence of storm wave-action. They are also indicative of the vicinity of the land.

\section{Unit 3}

In the lowermost part of this unit, sandstones are interpreted as beach rock deposits because they are coarse-grained, well sorted, and poorly cemented. The overlying stomatolites encrusting tree fragments, the shelly marls and limestones with brackish potamids gastropods and reworked stromatolites fragments were attributed to a restricted and brackish, inner platform-setting. Sporadic occurrence of mytilids, oysters and reworked coral fragments within deposits may indicate washover events during storms.

\section{Unit 4}

The lower part (log section: 43-54 m) of unit 4 shows a vertical deepening trend from a shallow outer platform-setting with turritellids limestones to an outer platform-setting represented by bryozoans (Smittina) silty marls and clayey limestones, and the overlying Rousset marls with globigerinids planctonic foraminifers (fig. 3). The sharp erosive surface and lag deposits, topping the brackish unit, suggest the onset of open marine conditions. The first turritellids limestone ( $\mathrm{mb} 2$ ), devoid of muddy matrix, was probably deposited in the upper shoreface zone, during storms as turritellids are especially infaunal gastropods. The shelly deposits were stabilized by scattered crusts of oysters and membraniporiform bryozoans in the upper part of the bed, and then covered by bioturbated fine-grained sands. This event both indicates a decrease in sedimentation rate and deepening with the first onset of the lower shoreface zone and deeper, outer platform-setting. Del Río et al. [2001] have assigned an inner to middle shelf-setting to similar mixed accumulation of turritellids and 
adeoniform bryozoan in the middle to late Miocene of Argentina. Smittina and especially Smittina cervicornis are frequently reported in the middle Miocene of Central Paratethys [e.g., Schmid et al., 2001; Moissette et al., 2007; Holcová and Zágoršek, 2008]. Moissette et al. [2007] and references therein defined Smittina cervicornis as an extant stenobathic species. According to the authors this species is characteristic for moderately deep environments $(30-100 \mathrm{~m})$ in the Mediterranean sea, and has an optimal depth range of 40-60 m. Schmid et al. [2001] and Holcová and Zágoršek [2008] respectively estimated a paleodepth range of 30-60 m to 50-100 m, for Smittina. These authors related the in situ development of Smittina in quiet, muddy environment with suboxic conditions and a low sedimentation rate. Such a setting is mostly reached in unit 4 as Smittina are deposited in a muddy sediment devoid of bioturbation. Nevertheless, these bryozoans have been transported. Only the last Smittina bed prior to Rousset marls deposition shows mostly in situ development with well-preserved, up to a few centimeters-long fragments of colonies. Thus the overlying marls may have deposited under the storm wave base in the offshore zone.

In the upper part (log section: $54-66 \mathrm{~m}$ ) of unit 4 , the gradual change from Rousset marls to coarsening-up, cross-bedded sandstones records increasing detrital inputs. The upward succession of planar laminations, HCS and megaripples, indicates the onset of lower and upper shoreface zones, respectively (fig. 3) [Borgovini, 2003]. Bioclasts such as stromatolites fragments were reworked and transported seaward from the inner platform. The overlying cross-bedded bioclastic deposits with locally abundant Smittina among other bryozoans, turritellids and few coral fragments were interpreted as hydraulic dunes generated in the upper shoreface zone. They represent a shallow outer platform-setting. The coral-level R3 indicates the onset of a coral-reef environment. The alternation of branching acroporitids-poritids breccia and muddy sediment suggests episodic storm-deposition in a relatively deep and sheltered lagoonal setting, as observed nowadays in the $\mathrm{Ca}$ ribbean [e.g., Scoffin, 1993]. The overlying coral carpet with bioturbated, clayey limestones and scattered domal and robust-branching coral-colonies was interpreted as a shallower lagoonal setting (figs 2, 3, 4D: mb 4). Common bioturbation and infaunal bivalves indicate low sedimentation rates while common bushy rhodoliths may be related to episodic currents. Andreieff and l'Homer [1972] described an exposure surface at the top of the coral-level R3. Above this surface, scattered, in-life position, oysters clumps and faviids bundles, buried by sandstones, represent a first attempt of reef initiation, prior to the onset of a new coral carpet at the top of lobe-shaped sandy limestones (coral level R4). The coral buildups and the bioclastic limestones may have deposited in a shallow outer-platform setting.

\section{Unit 5}

The alternance of shelly limestones (with either turritellids, or reworked infaunal bivalves), and marls indicates several environmental changes from shallow to deep outer-platform settings. Several lobe-shaped sandstone intervals represent recurrent strong detrital inputs. The Tuillière marls (fig. 3) with common globigerinids [Anglada, 1972] may correspond to a deeper outer-platform setting, under storm wave-action. These marls deposited in a deepening event, which lead to the drowning and demise of the underlying coral level R4. The Vaquette marls with common bivalves and less planktonic foraminifers, may have deposited in a shallower outer-platform setting. One shelly beds shows exposure revealed by a muddy silt vadose infilling the moldic porosity and sealed by the overlying sandstone. Finally the isopachous marine conglomerate (figs $2,3: \mathrm{mb} \mathrm{6}$ ) was interpreted as a gravel beach deposit as all gravels, including mollusc and reworked coral pebbles, are well-rounded and bored by sponges.

\section{Unit 6}

Well-rounded gravel and clean coarse-sands of the marine conglomerate are related to transport and winnowing by longshore current. The marine conglomerate corresponds to a littoral environment either in the foreshore zone or in the upper shoreface zone. The abundant mytilids and oysters in the overlying bioclastic limestone indicate the same environmental setting.

\section{Age model based on magnetobiostratigraphy}

The geomagnetic polarity record (GPR) anchored with biostratigraphic dating points (section II.3 and Oudet et al. [2010]) was correlated to the Astronomical Tuned Neogene Time Scale [ATNTS04, Lourens et al., 2004] (fig. 8). The time interval between the First Appearance Datum (FAD) of Sphenolithus delphix (23.21 Ma) and the FAD of Globoquadrina dehicens $(22.38 \mathrm{Ma})$ ranges from the subchron C6Cn.2r to the subchron C6Br, including 4 subchron boundaries which were recognized in GPR established in the present study. This allowed straightforwardly correlating the GPR to the ATNTS04. A few meters below the lowest occurrence (LO) of Globoquadrina dehicens, a subchron boundary was observed in the GPR and correlated to the $\mathrm{C} 6 \mathrm{Br}-\mathrm{C} 6 \mathrm{Bn} .2 \mathrm{n}$ boundary. This was done considering that the true LO of Globoquadrina dehicens (22.38 Ma) may be a few meters below the LO revealed by the biostratigraphic study. The vertical shift of the LO along the Carry section is explained by the absence of planktonic foraminifers within unit 3, which sedimentation represents a shallow and brackish, inner platform setting.

The time interval between the FAD of Globoquadrina dehicens (22.38 Ma) and the FAD of Paragloborotalia incognita (20.93 Ma) ranges from the subchron $\mathrm{C} 6 \mathrm{Br}$ to the subchron C6Ar. This interval comprises several boundaries of short subchrons. Using linear interpolation, the polarity change observed in the GPR at $\mathrm{z}=\sim 56 \mathrm{~m}$ was correlated to the C6Bn.1n-C6AAr.3r boundary. The polarity change located close to the LO of Paragloborotalia incognita was correlated to the C6AAn-C6Ar boundary. The absence of some subchrons in the GPR was attributed to the resolution of the study impeding the detection of very short subchrons and to no data intervals within the log.

The time interval between the FAD of Paragloborotalia incognita (20.93 Ma) and the FAD of Helicosphaera ampliaperta (20.43 Ma) ranges from the subchron C6Ar to the end of the subchron C6An.2n. This interval includes one polarity change which is missing in the GPR. This missing boundary was attributed either to no data interval in 


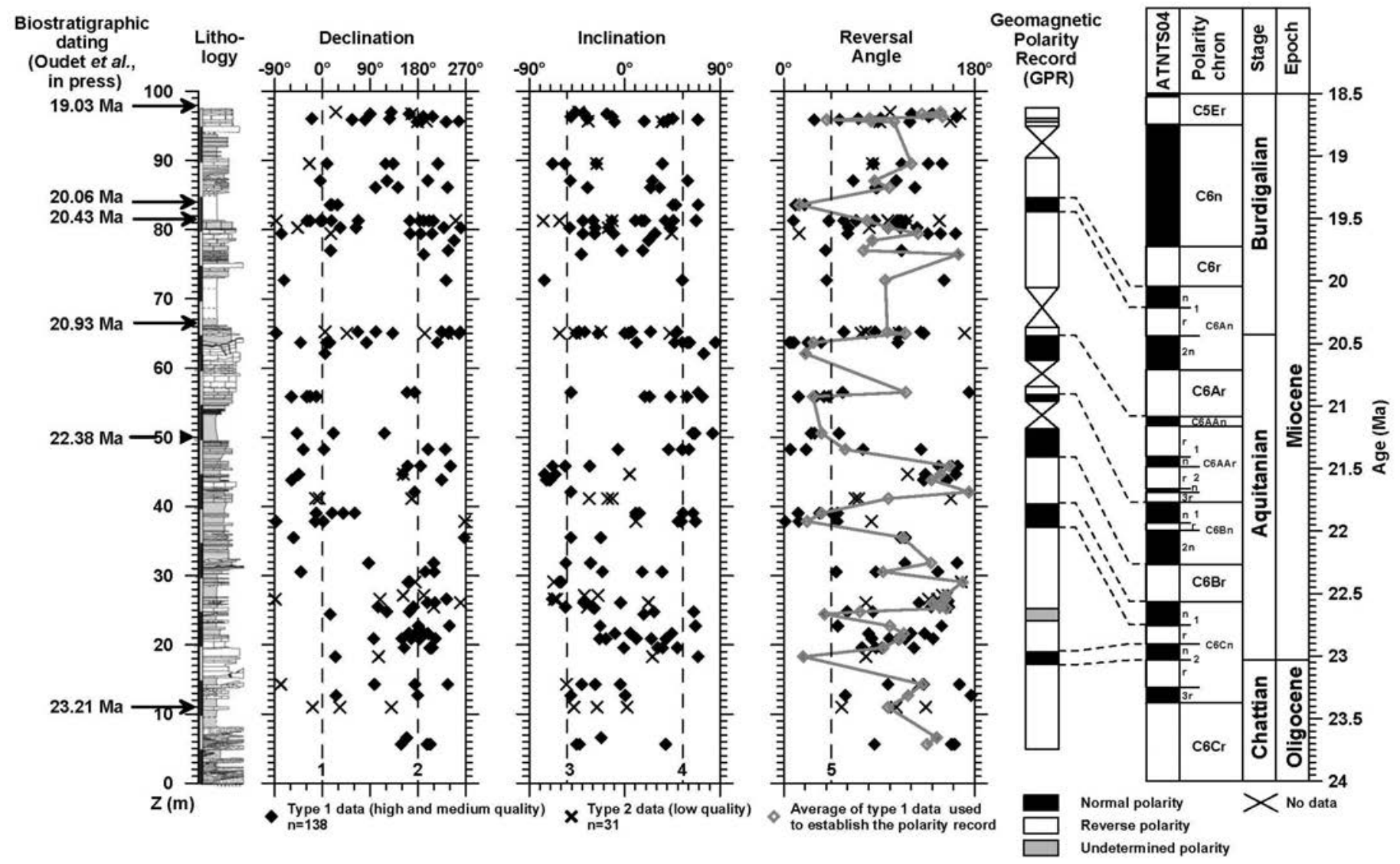

FIG. 8. - From left to right : biostratigraphic dating points [Oudet et al., 2010 and see section Biostratigraphie], composite log, declination, inclination and reversal angle profiles of the ChRM, deduced geomagnetic polarity record and correlation with a geomagnetic polarity reference scale [ATNTS04, Lourens et al., 2004]. Numbers correspond to declinations expected for a normal (1) or reverse (2) polarity, inclination expected for a reverse (3) or normal (4) polarity and threshold at $\mathrm{RA}=45^{\circ}(5)$ used to discriminate between normal and reverse polarity.

FIG. 8. - De gauche à droite : datations basées sur la bio-stratigraphie [Oudet et al., 2010 et voir $\$$ Biostratigraphie], log composite, profiles de déclinaison, d'inclinaison et de l'angle inverse de l'aimantation rémanente caractéristique, enregistrement de la polarité géomagnétique et corrélation avec l'échelle de polarité géomagnétique de référence [ATNTS04, Lourens et al., 2004]. Les nombres correspondent à la déclinaison attendue pour une polarité normale (1) ou inverse (2), à l'inclinaison attendue pour une polarité inverse (3) ou normale (4) et à la limite à 45० de l'angle inverse utilisée pour discriminer les polarités normales des polarités inverses.

the GPR or to a major exposure surface which could mark a hiatus of sedimentation.

The time interval between the FAD of Helicosphaera ampliaperta (20.43 Ma) and the FAD of Globigerinoides altiaperturus (20.06 Ma) ranges from the end of the subchron C6An.2n and the subchron C6An.1n. This interval includes one polarity change identified in the GPR at $\mathrm{z}=\sim 83 \mathrm{~m}$. The polarity change located close to the LO of Globigerinoides altiaperturus was correlated to the C6An.1n-C6r boundary.

Thanks to these correlations, the age model is composed of 9 paleomagnetic correlations extended by the biostratigraphic dating points located at both extremities of the sedimentary succession (fig. 9). The time span covered by the sedimentary succession is of $\sim 5 \mathrm{~m}$.y.

\section{DISCUSSION}

\section{Quality of the paleomagnetic record}

The paleomagnetic results show clear variations of the orientation of stable remanent magnetisations. This proves that no complete secondary remagnetization affected the studied rocks. On the contrary, other paleomagnetic studies led on sedimentary rocks of southeastern France reported Tertiary remagnetizations attributed either to orogenic fluids circulation [Aubourg and Chabet-Pelline, 1999; Kechra et al., 2003] or to burial diagenesis [Katz et al., 1998]. The present study, however, is noticeably different for the following reasons:

- the study area is located far away from the Alpine orogeny (several hundred kilometres). Hence, remagnetization linked to orogenic fluids did not affect the rocks of the study area. Concerning the Pyrenean orogeny, which deformed the Mesozoic substratum, the deformations ended in the Eocene times, i.e. before deposition of rocks of the present study;

- the Carry-le-Rouet sedimentary succession has not been buried. This excludes any burial diagenesis;

- the sedimentary facies (mostly shallow water carbonates including siliciclastics) of the present study are drastically different from the cited studies [Aubourg and Chabert-Pelline, 1999; Kechra et al., 2003; Katz et al., 1998] which are focused on deep sea carbonates and shales. 


\section{Age model and exposure surfaces}

The age model (fig. 9) allows to discuss on sedimentation rates and their relations to the distribution and significance of the different exposure surfaces.

The sedimentary column from $\mathrm{z}=10 \mathrm{~m}$ to $\mathrm{z}=37 \mathrm{~m}$ covers a time span of $\sim 450 \mathrm{ky}$, implying a sediment accumulation rate of $\sim 6 \mathrm{~cm} \mathrm{ky}^{-1}$ (segment 1 ). The sedimentary column from $\mathrm{z}=37 \mathrm{~m}$ to $\mathrm{z}=98 \mathrm{~m}$ covers a time span of $\sim$ 3.75 m.y., inducing a sediment accumulation rate of $1.62 \mathrm{~cm} \mathrm{ky}^{-1}$ (segment 2). These very low sedimentation rates can be attributed to sedimentary hiatuses and to diagenesis (compaction, dissolution...). Exposure surfaces evidenced in the log probably mark the major hiatuses but numerous short hiatuses, mostly undetectable, are distributed all along the $\log$. The role of hiatuses in the low sediment accumulation rates is, therefore, important but difficult to quantify. Nevertheless, the distribution of exposure surfaces is not homogeneous along the sedimentary column. Only one exposure surface was observed in segment 1 and no strong sedimentary hiatus was evidenced on this surface. Segment 2 showing lower sediment accumulation rates is marked by two exposure surfaces that could mark strong sedimentary hiatuses, especially the subareal exposure surface located at the top of R3 (see section Paleoenvironments). Coral growth may also participate to the increase of sedimentation rates but the growth rate is hard to estimate.

Considering the possible hiatuses marked by the occurrence of exposure surfaces, the age model is probably much smoothed. Nevertheless the age model points out that a major change in sediment accumulation rate is observed at $\sim 37 \mathrm{~m}$ in the sedimentary column that corresponds to an age of $22.75 \mathrm{Ma}$. This change could be related to local deformation taking place during rifting. This deformation can be responsible for changes in sediment supplies, bathymetric variations and changes in carbonates productivity affecting sedimentation rates.

\section{Paleoenvironments, global $\delta^{18} \mathrm{O}$ and relative sea level curves}

The paleoenvironments were precisely dated using the most realistic age model based on paleomagnetism and biostratigraphy (fig. 9). Wave energy zones boundaries were dated using linear interpolations between the correlation points of the age model. Paleoenvironments were compared to the $\delta^{18} \mathrm{O}$ and global sea level curves [Miller et al., 2005 and references therein] both recalibrated using

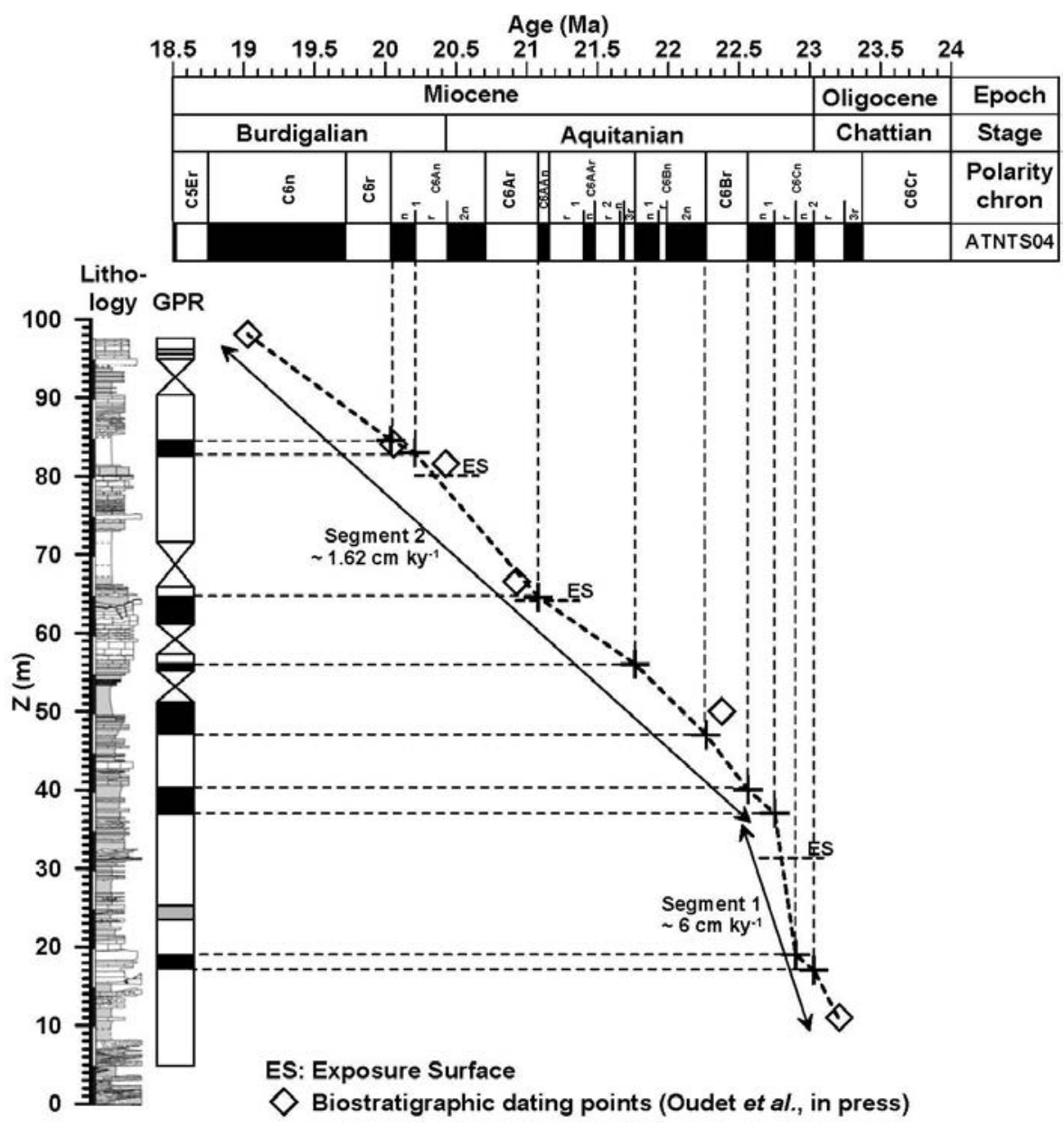

FIG. 9. - Age model built up from paleomagnetic correlation (black crosses) and biostratigraphic anchor points (open diamonds). The age model is built up from 9 paleomagnetic correlations and extended at both extremities by 2 biostratigraphic dating points. The main exposure surfaces are also noticed.

FIG. 9. - Modèle d'âge construit à partir des corrélations paléo-magnétiques (croix noires) et ancré par la bio-stratigraphie (diamants vides). Le modèle d'âge est construit à partir de 9 corrélations paléo-magnétiques et est étendu à ses deux extrémités par deux datations bio-stratigraphiques. Les principales surfaces d'émersion sont aussi indiquées. 
ATNTS04 [Lourens et al., 2004] and to the regional geodynamic events related to the Liguro-Provençal basin opening (fig. 10). The comparison between the paleoenvironments determined in the present study and global scale curves was possible since the Mediterranean Sea and the Atlantic Ocean were largely connected in the period considered [e.g., Séranne, 1999].

Late Oligocene-Early Miocene $\delta^{18} \mathrm{O}$ and global sea level variations Miller et al. [2005] are mostly influenced by Antarctic glaciations [Zachos et al., 2001; Naish et al., 2001]. The comparison between the paleoenvironments and the $\delta^{18} \mathrm{O}$ curve suggests that the first coral reef (R1, fig. 10) occurred during the glacial period characterised by high $\delta^{18} \mathrm{O}$ values at the end of the Oligocene (fig. 10). Nevertheless, the high $\delta^{18} \mathrm{O}$ values are not coherent with the increase observed in global sea level curve, depicting the end of the Late Oligocene glacial stage. This misfit could be attributed to the smoothness of the $\delta^{18} \mathrm{O}$ curve. Regarding the global sea level curve, the first coral reef occurred at the glacial-interglacial transition. The most diversified coral reef R3 occurred during the warmest period of the Aquitanian and marked by low $\delta^{18} \mathrm{O}$ values. Nevertheless, in spite of the good match between coral reef occurrences and warming phases, coral reefs described in the Mediterranean region in this period [Bosselini and Perrin, 2008] are not only influenced by temperature, but also by other parameters such as, for instance, trophic requirements [Brandano et al., 2009].

\section{Paleobathymetries, relative sea level curve and geodynamics}

Paleobathymetries estimated from the paleoenvironmental reconstructions were compared to the global sea level curve. In the present study, the time interval between 23.5 Ma and 20.6 Ma is marked by strong paleobathymetric variations with two phases of high sea level. These two phases were deduced from offshore zone characterisations succeeding several events of very low bathymetry (fig. 10). Paleobathymetric variations $(0$ to $50 \mathrm{~m})$ are in the same range than the global sea level variations $(-40$ to $+10 \mathrm{~m})$. Nevertheless, these variations do not fit the global sea level variations between 23.5 and $20.35 \mathrm{Ma}$. Especially the maximum depth of $\sim 50 \mathrm{~m}$ estimated in the $\log$ at $\sim 22.1 \mathrm{Ma}$ does not coincide with a high sea level. In addition, the offshore zone described between $21 \mathrm{Ma}$ and $20.75 \mathrm{Ma}$ does
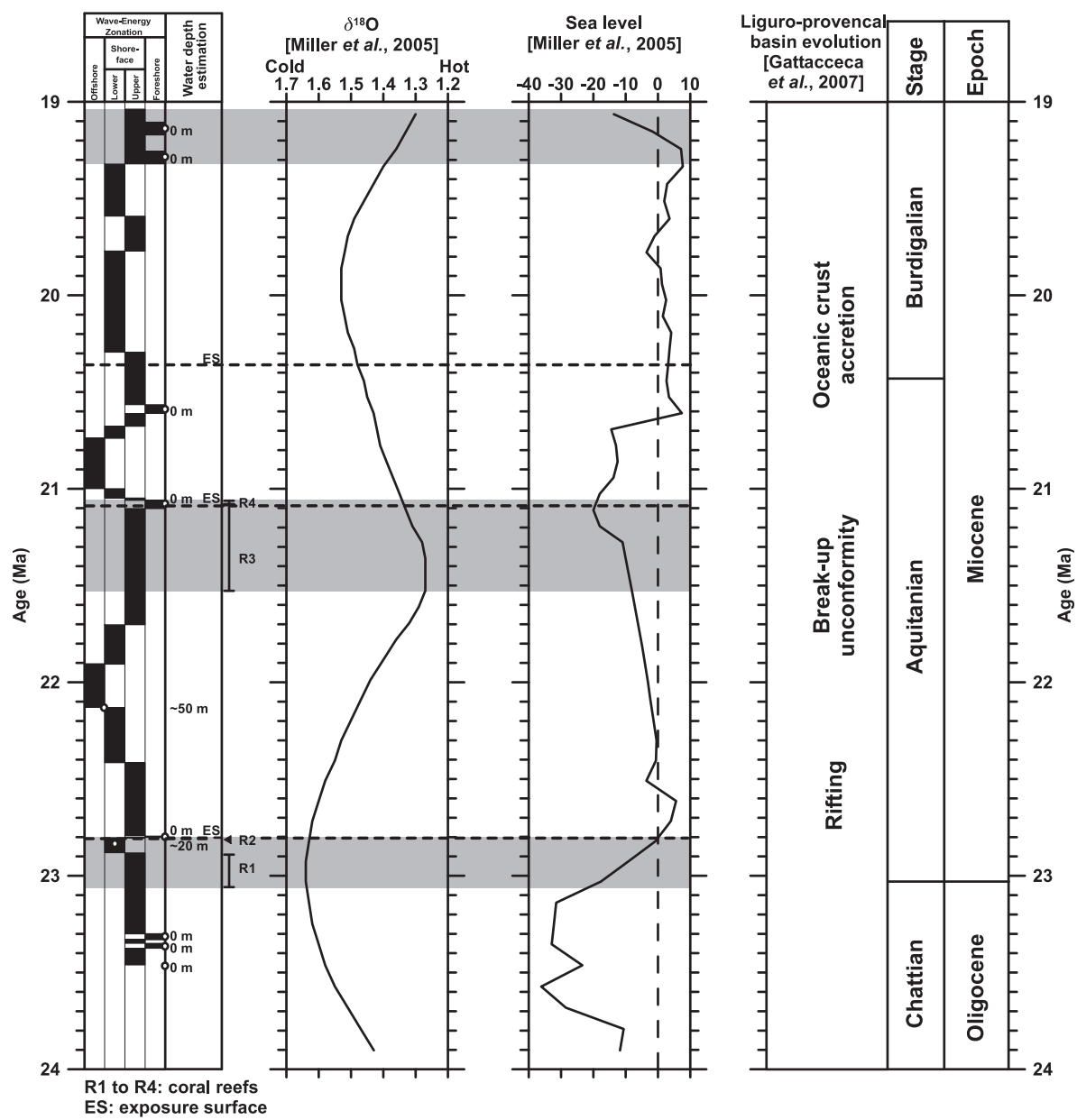

FIG. 10. - Dated paleoenvironmental reconstructions and comparison with global $\delta^{18} \mathrm{O}$ and sea level curves of Miller et al. [2005] and references therein both recalibrated according to ATNTS04 [Lourens et al., 2004]. Coral reefs (R1, R2, R3 and R4), exposure surfaces and water depth estimations are also noticed. To the right, geodynamic events succession associated to the Liguro-Provençal basin opening [Gattacceca et al., 2007 and reference therein].

FIG. 10. - Reconstructions paléo-environnementales datées et comparées aux courbes globales de $\delta^{18} \mathrm{O}$ et de variation du niveau marin de Miller et al. [2005] et références incluses, les deux courbes étant étalonnées suivant l'échelle des temps géologiques ATNTS04 [Lourens et al., 2004]. Les récifs coralliaires $(R 1, R 2, R 3$ et R4), les surfaces d'émersion et les estimations de profondeur d'eau sont aussi indiqués. A droite, succession des événements géodynamiques associés à l'ouverture du bassin liguro-provençal [Gattacceca et al., 2007 et références incluses]. 


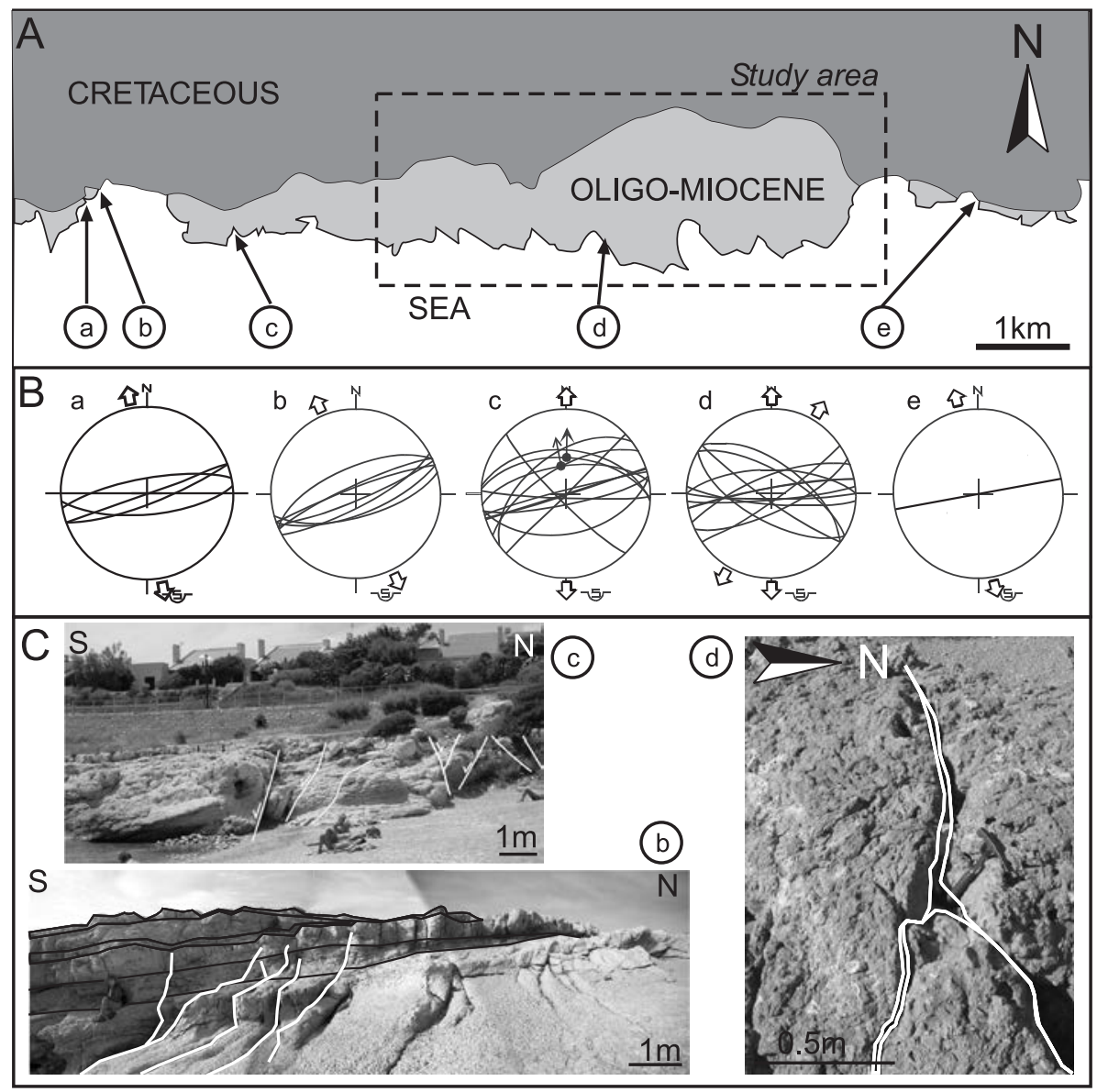

FIG. 11. - Syn-sedimentary normal faults and extensional fractures affecting the Oligo-Miocene rocks in and around the study area. A : location of faulted sites. a : parareefal Cap de Nautes unit, Petite Calanque ; b : parareefal Cap de Nautes unit, Boumandariel ; c : parareefal Cap de Nautes unit, calanque du Petit Nid ; d : bioclastic Carry unit, anse de la Tuilière ; e : Oligocene, Source Salée. B : stereographic projections of normal faults (with black arrows) and extensional fractures, lower hemisphere projection; with arrows indicating the estimate direction of extension. C (left) : exemple of syn-sedimentary normal faults in the parareefal Cap de Nautes unit of Boumandariel and of Calanque du Petit Nid ; and C (right) : example of syn-sedimentary extensional fracture filled with overlying sediments in Bioclastic Carry unit of Anse de la Tuilière.

FIG. 11. - Failles normales syn-sédimentaires et fractures en extension affectant les roches oligo-miocènes dans et autour de la zone d'étude. A : localisation des sites faillés. a : formation para-récifale du Cap de Nautes, Petite Calanque ; b : formation para-récifale du Cap de Nautes, Boumandariel ; c : formation para-récifale du Cap de Nautes, Calanque du Petit Nid; d : formation bioclastique de Carry, Anse de la Tuilière; e : Oligocène, Source Salée. $\mathrm{B}$ : projections stéréographiques des failles normales (avec les flèches noires) et fractures en extension, projection en hémisphère inférieur, avec flèches indiquant la direction d'extension estimée. C (gauche) : exemple de failles normales syn-sédimentaires dans la formation para-récifale du Cap de Nautes de Boumandariel et de la Calanque du Petit Nid; and $\mathrm{C}$ (droite) : exemple of fracture syn-sédimentaire en extension remplie des sédiments sus-jacents dans la formation bioclastique de Carry de l'Anse de la Tuillière.

not fit the increase of sea level occurring at $\sim 20.65$ Ma. The mismatch between paleobathymetry and global sea level is probably linked to local deformation.

Indeed, especially during rifting, movements along normal faults can be responsible for local increases of bathymetry. Syn-sedimentary brittle deformation in the Miocene has been measured in and around the study area (fig. 11). All faults are meter scale in size and show a normal displacement. Fractures are of the same scale and result from extension with syn-sedimentary filling. Faults and fractures are steep, striking $\mathrm{N}^{\circ} 80^{\circ}$ in average, which indicates a NNW-SSE direction of extension that affected the studied rocks during Aquitanian times. These brittle, syn-sedimentary deformations argue for a tectonic-driven, syn-rift subsidence in the Aquitanian.

Above the major exposure surface dated at $\sim 20.35 \mathrm{Ma}$, the quite stable paleobathymetry until $19.3 \mathrm{Ma}$ is followed by a decrease from 19.3 to $19 \mathrm{Ma}$. This variation is in agreement with the global sea level curve, which shows stable and relatively high level followed by a fall in the same time interval. Hence, from 20.35 to $19 \mathrm{Ma}$, the paleobathymetric variations match the global sea level variations. This shows that no local tectonics has changed the paleobathymetry. The absence of tectonics, the lack of exposure surface as well as the flat geometry of the sediments younger than $20.35 \mathrm{Ma}$ characterise post-rift sediments. This implies that the major exposure surface at $20.35 \mathrm{Ma}$ corresponds to the break up unconformity on the margin.

\section{CONCLUSIONS}

In the present study, we established a geomagnetic polarity record (GPR) for the Late Oligocene-Early Miocene carbonate succession of Carry-le-Rouet. The difficulty to access a high quality paleomagnetic signal in carbonates was 
overcome by the investigation of numerous samples per layer. Only 138 samples ( $62.5 \%$ of all the measured samples) were suitable to determine the geomagnetic polarity within 56 layers. The resulting GPR covers $80 \%$ of the sedimentary succession.

Using biostratigraphic constraints based on calcareous nannofossils and planctonic foraminifers [Oudet et al., 2010], the GPR was correlated to a reference geomagnetic polarity scale ATNTS04 [Lourens et al., 2004]. The resulting age model implies that:

- the sedimentary column covers a time span of $\sim 5 \mathrm{Ma}$ from the Late Chattian to the Early Burdigalian. Despite some changes in sediment accumulation rates and the presence of several exposure surfaces, no major sedimentary hiatus is evidenced. One inflexion of the age model curve shows a decrease of the sediment accumulation rates from 6 to $1.62 \mathrm{~cm} \mathrm{ky}^{-1}$ around $22.75 \mathrm{Ma}$. This change could be correlated to tectonic pulses occurring during rifting;

- paleoenvironments and paleobathymetries have been estimated using lithology, fossil assemblages, lateral variations of facies and geometry of sedimentary bodies. These incomes have been dated using the age model. This leads to the following conclusions:

- the Carry-le-Rouet sedimentary succession is an excellent climatic archive for the Late Oligocene to Early
Miocene. Indeed, coral reefs occurrences match the glacial to interglacial transition and the most diversified coral environment matches the warmest period of the Aquitanian;

- the paleobathymetric changes in the lowermost part of the sedimentary succession are not related to sea level variations. They are more likely controlled by the tectonic activity during rifting as deduced in section Paleobathymetries, relative sea level curve and geodynamics. For the highermost part of the sedimentary succession, the paleobathymetry matches the sea level changes. This reveals quiescent tectonic activity on the margin characteristic for the post-rift period coeval with oceanic crust accretion in the basin. The change in tectonic regime correlates with the noticeable exposure surface dated at $\sim 20.35 \mathrm{Ma}$, which is attributed to the break-up unconformity. This result considerably improves the accuracy of the break-up unconformity dating.

Acknowledgements. - This work was carried out with the financial support of the GDR "Marges" programme and the Carbonate Systems and Reservoirs Laboratory of Marseille (www.up.univ-mrs.fr/gsc). We thank Eric Ferré for improving the English. Two reviewers, Emmanuelle Vennin and Christian Crouzet, provided helpful comments that improve greatly this manuscript.

SGF associate editor: Pierre-Yves Collin.

\section{References}

Aïssaoui D.M., McNeIL D.F. \& KiRschvink J.L. (1990). - Magnetostratigraphic dating of shallow-water carbonates from Mururoa atoll, French Polynesia: Implications for global eustasy. - Earth Planet. Sci. Lett., 97, 102-112

Andreieff P., Anglada R., Carbonnel G., Catzigras F., Cavelier C., Chateauneuf J.-J., Colomb E., Jacob C., Lai J., L'Homer A., Lezaud L., Lorenz C., Mercier H. \& Parfenoff A. (1972). Contribution à l'étude de Carry-le-Rouet (Bouches du Rhône). $V^{e}$ Congrès du Néogène méditerranéen, Mémoires du BRGM, 3 132 pp.

AndreiefF P. \& L'Homer A. (1972). - Etude des microfaciès et interprétation des milieux de dépôts. In: ANDREIEFF P. et al., Eds, Contribution à l'étude de Carry-le-Rouet (Bouches-du-Rhône). $V^{e} C$ ongrès du Néogène méditerranéen, Mémoires du BRGM, 3, $71-83$

ANGlada R. (1972). - Etude des petits foraminifères. In: ANDREIEFF P. et al., Eds, Contribution à l'étude de Carry-le-Rouet (Bouchesdu-Rhône). - $V^{e}$ Congrès du Néogène méditerranéen, Mémoires du BRGM, 3, 29-33.

Aronson R.B. \& Precht W.F. (1997). - Stasis, biological disturbance, and community structure of a Holocene coral reef. - Paleobiology, 23, 326-346.

Aubourg C. \& Chabert-Pelline C. (1999). - Neogene remagnetization of normal polarity in the late Jurassic Black shales (Terres Noires) from southern Subalpine chains (French Alps). - Tectonophysics, 308, 473-486.

Bache F., Olivet J.-L., Gorini C., Aslanian D., Labails C. \& Rabineau M. (2010). - Evolution of rifted continental margins: The case of the Gulf of Lions (western Mediterranean basin). - Earth Planet. Sci. Lett., 292, 345-356.
Besson D., Parize O., Rubino J.-L., Aguilar J.-P., Aubry M.-P., Beaudoin B., Berggren W.A., Clauzon G., Crumeyrolle P., Dexcoté Y., Fiet N., Iaccarino S., Jimenez-Moreno G., Laporte-GalaA C., Michaux J., von Salis K., Suc J.-P., Reynaud J.-Y. \& Wernli R. (2005). - Un réseau fluviatile d'âge Burdigalien terminal dans le Sud-Est de la France: remplissage, extension, âge, implications. C. R. Géoscience, 337, 1045-1054.

BLow W.H. (1969). - Late Middle Eocene to Recent planktonic foraminiferal biostratigraphy. - 1st Intern. Congr. Planktonic Microfossils, Geneva, Proceedings, 1, 199-422.

Borgovini R. (2003). - Stratigraphie et faciès de la base du cycle Néogène de Basse Provence (littoral de la Nerthe: Carry-le-Rouet, Saussetles-Pins). Rapport Total, Exploration \& Production, DGEP/GSR/TG/THEM N03-006: 134.

Bosellini F.R. \& Perrin C. (2008). - Estimating Mediterranean Oligocene-Miocene sea-surface temperatures: an approach based on coral taxonomic richness. - Palaeogeogr., Palaeoclimatol., Palaeoecol., 258, 71-88.

Brandano M., Frezza V., Tomassetti L. \& Cuffaro M. (2009). - Heterozoan carbonates in oligotrophic tropical waters: The Attard member of the lower coralline limestone formation (Upper Oligocene, Malta). - Palaeogeogr. Palaeoclimatol. Palaeoecol., 274, 54-63.

Cabioch G., Montaggioni L., Thouveny N., Franck N., Sato T., Chazottes V., Dalmasso H., Payri C., Pichon M. \& Demah A.M. (2008). - The chronology and structure of the western New Caledonian barrier reef tracts. - Palaeogeogr., Palaeoclimatol., Palaeoecol., 268, 91-105

Chapronière G.C.H. (1975). - Palaeocology of Oligo-Miocene larger foraminiferida, Australia. - Alcheringa, 1, 37-58.

Chevalier J.-P. (1961). - Recherches sur les madréporaires et les formations récifales miocènes de la Méditerranée occidentale. Thèse, Paris XI. - Mém. Soc. géol. Fr., n. s., 93, 1-558.

Cogné J.-P. (2003). - PaleoMac: A Macintosh ${ }^{\mathrm{TM}}$ application for treating paleomagnetic data and making plate reconstructions. - Geochem. Geophys. Geosyst., 4, (1), 1007, doi: 10.1029/2001GC000227. 
Conesa G., Demory F., Oudet J., Cornée J.-J., Münch P. \& Rubino J.-L. (2005a). - Journée 1 - l'Oligo-aquitanien de la Côte Bleue: les systèmes récifaux et bioclastiques du littoral méditerranéen entre l'Estaque et la Couronne. In: BEsson et al., Eds, Les systèmes oligo-miocènes carbonatés et clastiques de Basse-Provence. Des témoins de l'évolution géodynamique de la marge provençale et du bassin d'avant-pays alpin. - Excursion commune 10ième congrès ASF - GDR “" Marges Golfe du Lion “, p. 19.

Conesa G., Favre E., Münch P., Dalmasso H. \& Chaix C. (2005b). - Biosedimentary and paleoenvironmental evolution of the southern Marion platform from the middle to late Miocene (northeast Australia, ODP Leg 194, Sites 1196 and 1199), 1-38. In: F.S Anselmetti, A.R. Isern, P. Blum And C. Betzler, Eds. - Proc ODP, Sci. Results, 194.

Del Río C.J., Martínez S.A. \& Scasso R.A. (2001). - Nature and origin of spectacular marine Miocene shell beds of northeastern Patagonia (Argentina): paleoecological and bathymetric significance. - Palaios, 16, 3-25.

Demory F., NowACZyK N.R., WitT A. \& OBERhÄNSLi H. (2005). - High-resolution magnetostratigraphy of late Quaternary sediments from Lake Baikal, Siberia: timing of intracontinental paleoclimatic responses. - Global and Planetary Change, 46, (1-4), 167-186.

Dezes P., Schmid S.M. \& Ziegler P.A. (2004). - Evolution of the European Cenozoic rift system: interaction of the Alpine and Pyrenean orogens with their foreland lithosphere. - Tectonophysics, 389, 1-33.

EINSELE G. (2000). - Sedimentary basins: evolution, facies, and sediment budget: Second, completely revised and enlarged edition. Springer, Berlin, $792 \mathrm{p}$.

Fisher R.A. (1953). - Dispersion on a sphere. - Proc. Roy. Soc. London, Ser. A, 217, 295-305.

Fournier F., Montaggioni L. \& Borgomano J. (2004). - Paleoenvironments and high-frequency cyclicity from Cenozoic southeast Asian shallow-water carbonates: a case study from the Oligo-Miocene buildups of Malampaya (Offshore Palawan, Philippines). - Mar. Petrol. Geol., 21, 1-21.

GALloni F. (2003). - Organisation sédimentaire et anatomies récifales des systèmes carbonatés à silicoclastiques oligo-miocènes inférieurs de Provence et du bloc corso-sarde. - PhD Thesis, Université of Provence, Marseille, 300 p.

GatTACCECA J. (2000). - Cinématique du bassin liguro-provençal entre 30 et $12 \mathrm{Ma}$. Implications géodynamiques. - PhD Thesis, Ecole des Mines de Paris, 299 pp.

Gattacceca J., Deino A., Rizzo R., Jones D.S., Henry B., Beaudoin B. \& VADEBoIn F. (2007). - Miocene rotation of Sardinia: New paleomagnetic and geochronological constraints and geodynamic implications. - Earth Planet. Sci. Lett., 258, 359-377.

Gorini C., Le Marrec A. \& Mauffret A. (1993). - Contribution to the structural and sedimentary history of the gulf of Lions (western Mediterranean), from the ECORS profiles, industrial seismic profiles and well data. - Bull. Soc. géol. Fr., 164, 353-363.

Gradstein F.M., Ogg J.G., Smith A.G., Agterbero F.P., Bleeker W., Cooper R.A., Davydov V., Gibbard P., Hinnov L., House M.R., Lourens L., Luterbacher H.-P., McArthur J., Melchin M.J., Robb L.J., Shergold J., Villeneuve M., WardlaW B.R., Ali J., Brinkhuis H., Hilgen F., Hooker J., Howath R.J., Knoll A.H., Laskar J., Monechi S., Powell J., Plumb K.A., RAFFi I., Rhöl U., SAnfilippo A., Schmitz B., Shackleton N.J., Shields G.A., Strauss H., Van Dam J., Veizer J., Van Kolfschoten T. \& Wilson D. (2004). - A geological time scale. - Cambridge University press, 500p.

HolcovÁ K. \& ZÁGORŠEK K. (2008). - Bryozoa, foraminifera and calcareaous nannoplankton as environmental proxies of the "bryozoan event" in the Middle Miocene of the Central Paratethys (Czech Republic). - Palaeogeogr. Palaeoclimatol. Palaeoecol., 267, 216-234.

Hrouda F. (1994). - A technique for the measurement of thermal changes of magnetic susceptibility of weakly magnetic rocks by the CS-2 apparatus and KLY-2 Kappabridge. - Geophys. J. Int., 118 , (3), 604-612.

Katz B., Elmore R.D., Cogoini M. \& Ferry S. (1998). - Widespread chemical remagnetization: orogenic fluids or burial diagenesis of clays? - Geology, 26, (7), 603-606.
Kechra F., Vandamme D. \& Rochette P. (2003). - Tertiary remagnetization of normal polarity in Mesozoic marly limestones from SE France. - Tectonophysics, 362, 219-238.

KIRSHVINK J.L. (1980). - The least square line and the analysis of paleomagnetic data. - Geophys. J. R. Astron. Soc., 62, 699-718.

Lourens L.J., Hilgen F.J., Laskar J., Shackleton N.J. \& Wilson D. (2004). - The Neogene period. In: F.M. Gradstein, J.G. OGG, A.G. Smith, Eds., A geologic time scale. - Cambridge Univ. Press, 409-440.

Maillard A., Gaullier V., Vendeville B.C. \& Odonne F. (2003). Influence of differential compaction above basement steps on salt tectonics in the Ligurian-Provençal basin, northwest Mediterranean. - Mar. Petrol. Geol., 20, 13-27.

Matheron P. (1839). - Essai sur la constitution géognostique des Bouches-du-Rhône. - Répertoire des Travaux de la Société de Statistique de Marseille, 3, $134 \mathrm{p}$

Maurel-Ferrandini M. (1976). - Reconstitution paléogéographique du Burdigalien du littoral de la chaîne de la Nerthe et de la région des étangs (Bouches-du-Rhône, France). - PhD Thesis, University of Provence, Marseille, $87 \mathrm{p}$.

Miller K.G., Kominz M.A., Browning J.V., Wright J.D., Mountain G.S., Katz M.E., Sugarman P.J., Cramer B.S., Christie-Blick N. \& PEKAR S.F. (2005). - The Phanerozoic record of global sea-level change. - Science, 310, 1293-1298.

Moissette P., Dulai A., Escarguel G., Kázmér M., Müller P. \& Saint MARTIN J.-P. (2007). - Mosaic of environments recorded by bryozoan faunas from the middle Miocene of Hungary. - Palaeogeogr. Palaeoclimatol. Palaeoecol., 252, 530-556.

Monleau C., Arnaud M. \& Catzigras F. (1988). - L'Oligocène supérieur marin de la Nerthe (B-d-R): nouvelles données sédimentologiques et paléogéographiques dans le cadre de la géodynamique de la Méditerranée occidentale. - C. R. Acad Sci., Paris, 306, 487-490.

Naish T.R., Woolfe K.J., Barrett P.J., Wilson G.S., Atkins C., Bohaty S.M., Bucker C., Claps M., Davey F., Dunbar G., Dunn A., Fielding C.R., Florindo F., Hannah M., Harwood D.M., WatKins D., Henrys S., Krisseck L., Lavelle M., VAn der Meer J.J.P., McIntosh M.C., Niessen F., Passchier S., Powell R., Roberts A.P., Sagnotti L., Scherer R.P., Strong C.P., Talarico F., Verosub K.L., Villa G., Webb P-N. \& Wonik T. (2001). - Orbitally induced oscillations in the East Antarctic ice sheet at the Oligocene/Miocene boundary. - Nature, 413, 719-723.

NuRY D. (1990). - L'Oligocène de Provence méridionale: stratigraphie, dynamique sédimentaire, reconstitutions paléogéographiques. PhD Thesis, University of Provence, Marseille, $411 \mathrm{p}$.

Nury D. \& Thomassin B.A. (1994). - Paléoenvironnements tropicaux, marins et lagunaires d'un littoral abrité (fonds meubles à bancs coralliens, lagune évaporitique) à l'Oligocène terminal (région d'Aix-Marseille). - Géol. Méditerr., 21, 95-108.

OgG J.G., OGg G. \& Gradstein F.M. (2008). - The concise geological time scale. - Cambridge University Press, $184 \mathrm{p}$.

OudET J. (2008). - Etude terre-mer de la transition syn-rift/post-rift sur les marges de l'océan liguro-provençal: apports de la modélisation géologique 3D et de la chronostratigraphie intégrée. - PhD Thesis, University of Provence, Marseille.

Oudet J., Münch Ph., Borgomano J., Quillévéré F., Melinte M., DemoRY F., VISEUR S. \& CORNÉE J-J. (2010). - Land and sea study of the northeastern golfe du Lion rifted margin. In: X. LE PICHON and C. Rangin, Eds, Geodynamics of the France Southeast Basin. - Bull. Soc. géol. Fr., 181, 6, 591-607.

Riegl B. \& Piller W. E. (1999). - Coral frameworks revisited-reefs and coral carpets in the northern Red Sea. - Coral Reefs, 1, 241-253.

Schmid H.P., Harzhauser M., Kroh A., Coric S., Rögl F. \& Schultz O. (2001). - Hypoxic events on a middle Miocene carbonate platform of the Central Paratethys (Austria, Badenian, $14 \mathrm{Ma}$ ). Ann. Naturhist. Mus. Wien, 102A, 1-50.

Schneider J., de Wall H., Kontny A. \& Bechstädt T. (2004). - Magnetic susceptibility variations in carbonates of the La Vid Group (Cantabrian Zone, NW-Spain) related to burial diagenesis. - Sediment. Geol., 166, 73-88. 
SCOFFIN T.P. (1993). - The geological effects of hurricanes on coral reefs and the interpretation of storm deposits. - Coral reef, 12, 203-221.

SÉRANNE M. (1999). - The Gulf of Lion continental margin (NW Mediterranean) revisited by IBS: an overview. In: B. DURAND, L. JOLIvet, F. Horváth AND M. SÉrAnne, Eds, The Mediterranean basins: Tertiary extension within the Alpine orogen. - Geol. Soc. London, Spec. Publ., 156, 15-36.
Westphal M., Orsini J. \& Vellutini P. (1976). - Le microcontinent corso-sarde, sa position initiale: données paléomagnétiques et raccords géologiques. - Tectonophysics, 30, 141-157.

Zachos J.C., Shackleton N.J., Ravenaugh J.S., Paelike H. \& Flower B.P. (2001). - Climate response to orbital forcing across the Oligocene-Miocene boundary. - Science, 292, 274-278.

ZiJdeRVELD J.D.A. (1967). - Demagnetization analysis of results. In: Methods in paleomagnetism. - Elsevier, Amsterdam, 254-286. 